\title{
OVERVIEW OF THE ECOLOGY OF THE BRAS D'OR LAKES WITH EMPHASIS ON THE FISH
}

\author{
TIMOTHY C. LAMBERT \\ Marine Fish Division \\ Fisheries and Oceans Canada \\ Bedford Institute of Oceanography \\ Dartmouth, Nova Scotia
}

\begin{abstract}
In this review of biological research in the Bras d'Or Lakes, groundfish trawl surveys from 1952, 1967 and 1999/2000 are compared and changes in abundance and distribution of major groundfish species are noted. The most common species were winter flounder (Pseudopleronectes americanus) and cod (Gadus morhua). The biggest change over the nearly 50 year span of these investigations was in the abundance of American plaice (Hippoglossoides platessoides) which used to be very common in the Lakes but were rare in recent surveys. The Lakes contain at least one, and probably two, resident populations of cod and are home to a population of spring-spawning herring. The unique nature of the Bras d'Or Lakes is emphasized in relation to the diversity of species they contain. Glacial relicts, survivors since the last ice age, can be found within a few kilometres of warm temperate species, persisting since the 'climatic optimum'. The Lakes are ideally suited for ecosystem studies, for in addition to their unique biology, they are readily accessible and can be easily sampled on a daily basis.
\end{abstract}

Ce document passe en revue les recherches biologiques effectuées par le passé dans les lacs Bras d'Or et présente les résultats d'études récentes et en cours. Nous comparons les relevés du poisson de fond réalisés en 1952, en 1967 et en 1999/2000 en notant les changements dans l'abondance et la répartition des principales espèces de poisson de fond. Dans tous ces relevés, les espèces les plus courantes étaient la plie rouge (Pseudopleronectes americanus) et la morue (Gadus morhua). Le plus important changement observé sur les 50 ans que couvrent ces études a touché la plie canadienne (Hippoglossoides platessoides), que l'on trouvait très couramment dans les lacs par le passé mais qui était rare dans les relevés récents. Les lacs contiennent au moins une et probablement deux populations résidantes de morue et une population de hareng qui fraie au printemps. Le document met l'accent sur la relation entre la nature particulière des lacs Bras d'Or et la diversité des espèces qu'ils abritent. Des espèces reliques de l'âge glaciaire y vivent à quelques kilomètres d'espèces caractéristiques d'un climat tempéré chaud qui persistent depuis la période de réchauffement médiéval. Les lacs se prêtent parfaitement à des études écosystémiques, car, en plus d'être uniques sur le plan biologique, ils sont faciles d'accès, et on peut aisément y effectuer des échantillonnages quotidiens.

\section{Introduction}

Many people are surprised to learn that the Bras d'Or Lakes are not actually lakes in the usual sense of the word, that is, a body of fresh water. At first encounter they have every appearance of lakes, being bordered by low mountains to the west and rolling hills to the east and, unlike the nearby ocean, appear to have no tide. However, a taste of the water and an examination of the fish caught by youngsters off a dock will quickly dispel this first impression. The water is distinctly salty and the fish on the dock will probably be a cunner (sea perch), cod or even a mackerel. This inland sea, one of Canada's scenic highlights, sustains an ecosystem which is unique in many respects.

The Bras d'Or Lakes are situated in Cape Breton Island at the northern end of Nova Scotia. This body of water of about $1,100 \mathrm{~km}^{2}$ is essentially an enclosed estuary with three outlets to the sea. The Great Bras d'Or Channel and the Little Bras d'Or Channel connect with Sydney Bight to the north, and St. Peter's Canal gives access to Chedabucto Bay to the south (Fig 1). Only the Great Bras d'Or Channel is large enough to permit any significant exchange of water. The Bras d'Or Lakes watershed is about 2500 $\mathrm{km}^{2}$; this area added to that of the Lakes themselves gives a total catchment area of $3600 \mathrm{~km}^{2}$ (Krauel, 1976). 


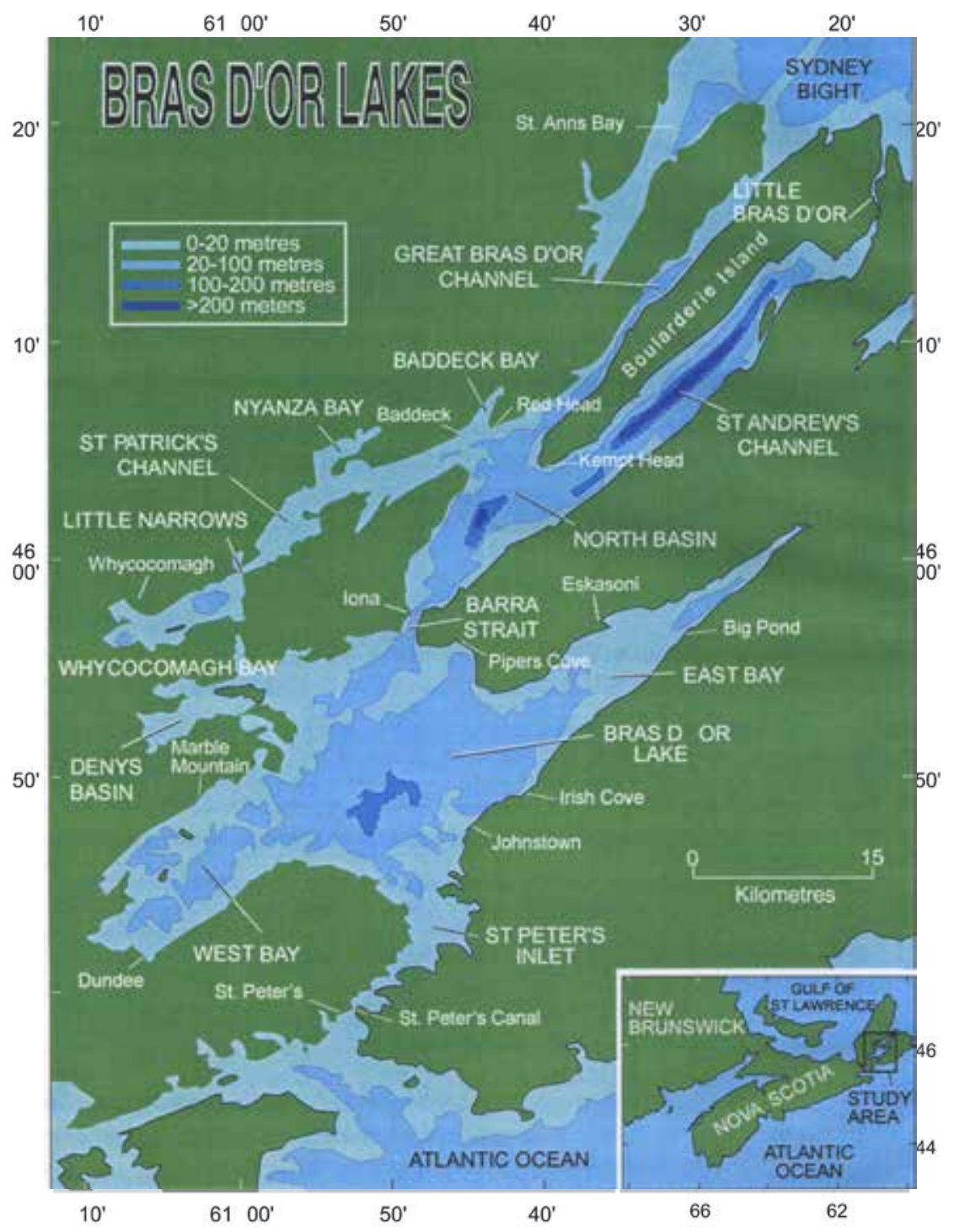

Fig 1 Map of the Bras d'Or Lakes indicating places mentioned in the text.

Input from six rivers and restricted access to the ocean keeps salinity in the range of 20 to 26, whereas, sea water just outside the Lakes in Sydney Bight ranges from about 28 to 32 . The Lakes are usually ice covered in the winter and surface waters often exceed $20^{\circ} \mathrm{C}$ in the late summer, particularly in smaller, shallow bays (Petrie and Bugden, 2002).

The waters of the Bras d'Or Lakes are characterised by a two-layer system; a low salinity surface layer which has a wide annual range in temperature and a lower layer 
of higher salinity in which temperature range is much less pronounced. In general, surface water moves toward the entrance of the Lakes and out into Sydney Bight and is replaced with outside oceanic water which enters the Lakes near the bottom and flows underneath the surface layer (Krauel, 1976; Petrie and Bugden, 2002). With the exception of restricted channels, there is little mixing between these layers except for winter months when higher winds and wave action disrupt the stability of this system. In some areas where currents and exchange rates are very low, the amount of dissolved oxygen can become quite depressed and in Whycocomagh Bay, anoxic (no oxygen) conditions exist (Petrie and Bugden, 2002; Strain and Yeats, 2002).

A wide range of habitats, with bottom types ranging from rocky through gravel and sand to mud, can be found. These include marshy flats, "barachois" (small, shallow pond-like embayments, more or less cut off from the main lake by a sandbar), bays, inlets of various depths (some well-flushed and others anoxic), deep basins and a trench about $280 \mathrm{~m}$, a depth matched only beyond the edge of the continental shelf. Given the diversity of habitats it is not surprising to find that the Bras d'Or Lakes are home to a wide variety of marine life. The species within the Lakes are, in general, characteristic of those occurring along Nova Scotia's Atlantic coast. However, the Bras $d^{\prime} \mathrm{Or}$ is probably unique in that it is also home to both warm and cold water species which are rare in this part of the world.

Ecologists divide the earth into regions, which have characteristic faunal assemblages, which can be related to climatic conditions. In the Northern Hemisphere, these zoogeographical regions, ranging from cold water to warm, are Arctic, boreal, temperate and tropical. The boundaries between these regions are not distinct and arctic-boreal and boreal-temperate borders in the western North Atlantic tend to fluctuate according to the season; transition zones between zoogeographical areas are broad. Nova Scotia is in the boreal region, which roughly extends from south-east Labrador in the north to Cape Cod in the south (Ekman, 1953). Although a distinct assemblage of animals dominates this zone, Arctic species are intermittently carried south into the boreal zone by the Labrador Current, and conversely, temperate and even subtropical species are regularly carried far north of their normal ranges by the Gulf Stream. Most obvious of these transient visitors are pelagic creatures such as the sunfish and sea turtle. Less noticed because of their smaller size, but more common, are planktonic transients. In summary, there is no smooth, transition of northern species to southern species in this area of the world (Bousfield and Thomas 1975).

Many of the fish in the Bras d'Or Lakes are resident there and most are demersal or bottom living. Migratory pelagic (living in surface and mid-waters) species, such as mackerel, herring and salmon, are seasonal visitors to the Lakes. Species that do, or did, support commercial fisheries are winter flounder and herring. The winter flounder fishery ended in 1992 with the barring of commercial draggers from the Lakes (Maclsaac, 2001), and the spring herring fishery was stopped in 1999 because of the imminent collapse of the stock, most likely due to overfishing. Cod, mackerel, smelt, and eel support limited recreational fishing.

Some invertebrates fished in the Bras d'Or Lakes are lobsters, oysters, scallops and rock crab. Lobsters are fished in most rocky areas throughout the Lakes but present landings are poor, which may be a result of overfishing or because of poor larval survival resulting from reduced salinity (Tremblay, 2002). Scallop and rock crab fishing is limited to a small area at the north end of the Great Bras d'Or Channel immediately adjacent to Sydney Bight. Here, the higher salinity bottom water entering the Lakes from the Bight is salty enough to support these 2 species, but probably not farther into the Lakes, since it becomes progressively diluted by low salinity Lakes' 
water. Oysters, once common throughout the Bras d'Or Lakes, have been seriously depleted on public beds due to overharvesting (Dennis, 2001) and are now found in quantity only at lease sites, where they form the basis of an important and growing aquaculture industry. The presence of the green crab, a recently introduced non-native species, is of great concern since it is known to feed voraciously on juvenile bivalve molluscs such as clams and oysters (Tremblay, 2002). Rainbow trout and salmon are also farmed in the Lakes.

Despite the cultural and economic importance of the Bras d'Or Lakes to Cape Breton Island, and their accessibility, we have but a rudimentary knowledge of their biology. However, the limited research that has been carried out does seem to indicate that the Lakes are unique, at least biologically. They have many similarities with adjacent Sydney Bight, but also have intriguing differences. This paper will review what is known of the Lakes' biology, highlighting unique aspects, and as well will examine the groundfish community, comparing recent survey work to surveys carried out over 30 and 50 years ago.

\section{Previous Studies}

Much of the research conducted within the Bras d'Or Lakes in the past was motivated by an interest in aquaculture. Some of the results of these early studies were presented at a conference in 1975 (McKay, 1976), where information on water chemistry (Young, 1976); physical oceanography (Krauel, 1976); primary production (Wright, 1976); and marine biology (Black, 1976) were given. For those interested in engineering design of culture systems, the remainder of the proceedings are a useful reference. A description of the Bras d'Or region and a comprehensive bibliography of literature relating to the Bras d'Or Lakes is being prepared by Kenchington and Carruthers ${ }^{1}$ on behalf of the Unama'ki Institute of Natural Resources.

Primary Production Phytoplankton (planktonic plants) are very important in marine ecosystems, for they are the base food source upon which virtually all marine life depends. Geen (1965), Geen and Hargrave (1966), Wright (1976) and recently Strain and Yeats (2002) suggest that the level of phytoplankton growth (primary production) in the Lakes is low, since nutrient input was small. Strain and Yeats (2002) estimate that the contribution of sewage and other man-made sources of nutrients is minor; although, in some localised areas, such as barachois and the western end of Whycocomagh Bay there is sufficient build up, together with natural nutrients, to cause eutrophication (explosive growth of plant life which chokes waterways). The resulting anoxic conditions kill marine organisms and produce sulfides during decomposition.

Plankton. The best way to determine the range of species that live in the ocean is to tow a plankton net through it. Many animals that live in the sea, whether they are fishes or invertebrates, or whether they live on the bottom or swim freely in the water column, have a planktonic stage that drifts with the current. This may be an egg, a larva, or both. Thus in a plankton sample it is possible to find larval stages of animals as diverse as fish, clams, oysters, scallops, starfish, sea urchins, marine sea worms, barnacles, crabs and lobsters. These are mixed with microscopic animals e.g. copepods, whose entire life span is planktonic.

The National Museum of Canada undertook a series of investigations of the benthos and plankton in the Lakes during the summer of 1981. Shih et al. (1988) directed their

1 An unpublished document "Unamapaqt: A description of the Bras d'Or marine environment" commissioned by the Unama'ki Environmental Committee of the Union of Nova Scotia Indians 
attention to the copepod fauna, tiny crustaceans that are the food source for many larval fish and even some adult fish, which strain them from the water with specialised gill rakers. Fifteen species of copepods (Fig 2) were found, but these species were not evenly distributed. Pseudocalanus minutus, Oithona similis, Temora longicornis and Tortanus discaudatus were the most common and found throughout the Lakes. Bras d'Or Lake had the lowest diversity with virtually only these 4 species present. St. Andrew's Channel had the highest diversity including the only occurrences of Anomalocera opalus, Calanus finmarchicus, Calanus hyperboreus and Microcalanus pusillus (a cold water species common in the Arctic).

Plankton samples were collected in the Lakes by the federal Department of Fisheries and Oceans (DFO) during the 1990s, generally during May and early June. The focus

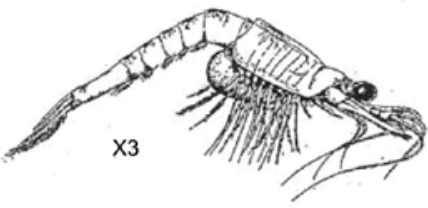

Mysid

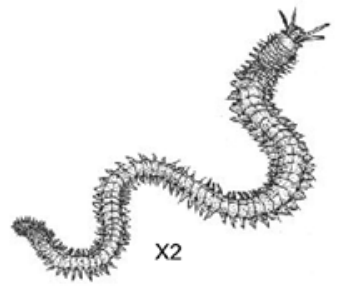

Polychaete
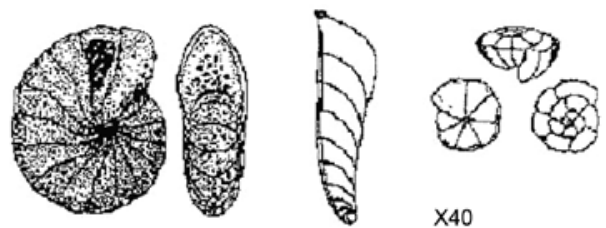

$\times 40$

\section{Foraminifera}

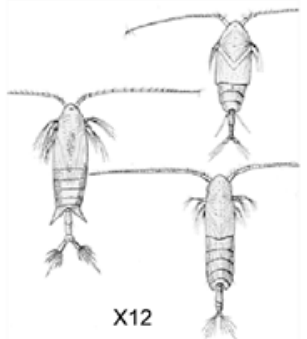

Copepods

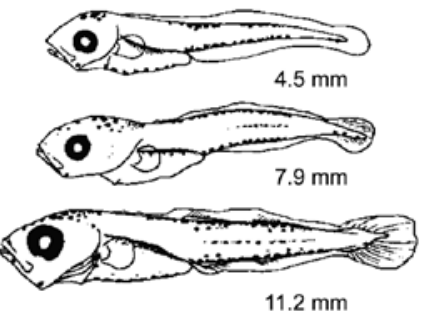

Cod larvae

Fig 2 Selected invertebrates and fish larva occurring in the Lakes and mentioned in the text. 
of this work was to determine time and location of spawning of fish species through collection of eggs and larvae. In 1991, as part of a cod egg survey of Sydney Bight, a few tows were made in the Bras d'Or Lakes. Later, a dedicated survey was made of the Lakes during May and June of 1996. In 2000, an annual plankton survey was begun as part of a cooperative venture between the DFO and the Eskasoni Fish and Wildlife Commission (EFWC). The samples are being analysed at EFWC and results will be reported elsewhere; however, a few highlights of their ichthyoplankton (larval fish) content bear mentioning. The most abundant fish eggs found were those of the four-beard rockling (Enchelyopus cimbrius), cunner (Tautogolabrus adspersus), windowpane flounder (Scophthalmus aquosus) and mackerel (Scomber scombrus). The most common fish larvae were four-beard rockling, winter flounder (Pseudopleuronectes americanus), cod (Gadus morhua) and smelt (Osmerus mordax). Some species known to frequent the Lakes were absent or poorly represented in the samples due to the timing of the surveys. Cod eggs in an early stage of development were scarce because the surveys were too late to catch the peak of cod spawning which apparently occurs in late February and early March; however, cod larvae (Fig 2) were common. On the other hand, the surveys occurred just as mackerel were beginning to spawn; hence their eggs were plentiful but larvae were not, since few eggs had yet hatched.

Benthic Invertebrates During groundfish trawl surveys in 1951-1952 (Black, 1976), 1967 (MacDonald, 1968) and 1999-2000 (this paper), the presence of the larger bottom dwelling invertebrates was documented. Tremblay (2002) presents details on these species and a brief overview of species he did not include will be presented here.

Mysid shrimps Mysid shrimps (Fig 2) live in close association with the ocean floor and are an important food source for many bottom-feeding fish. Black (1958) studied these small shrimps from 3 locations in the Bras d'Or (see 'Groundfish trawl surveys' below). He identified 5 species, the most common of which were Neomysis americana and Mysis stenolepis. These two were found in all parts of the Lakes and are boreal inshore forms that have a wide temperature and salinity tolerance. Mysis mixta and Erythrops erythrophthalma are Arctic-boreal forms which avoid warm water and were found in the cold water of deep areas, although they moved to shallower depths in the winter when surface waters cooled. The fifth species, Mysis oculata is a true Arctic animal and is generally found in shallow polar regions. Here, at considerable distance from its normal home range, it survives in the cold, deep waters of the Lakes.

Polychaete worms Fournier and Pocklington (1984) identified more than 70 species of polychaetes (marine worms) from benthic samples taken from all parts of the Lakes (Fig 2). The Great Bras d'Or Channel had the greatest number of species with 43, 19 of which occurred only in the Channel, and not in other areas of the Lakes. They recognised a range of zoogeographical affinities from warm water temperate species through boreal to Arctic. St. Patrick's Channel and Whycocomagh Bay had the poorest representation of polychaete worms with only 15 species recorded. Probably the most common polychaete found throughout the Lakes was Euchone papillosa. This worm constructs a slender clay-walled tube within which it lives. These tubes often form dense mats to which a small clam, Hiatella arctica, attaches (Fournier and Pocklington, 1984. One of the Arctic 'relicts' found in the Lakes was Clymenura polaris, whose occurrence here is the first record south of Davis Strait in the Arctic.

Foraminifera Vilks (1967) surveyed the foraminifera of the Bras d'Or Lakes (Fig 2). The tiny shells of these marine protozoa form a calcareous ooze which, over time, can fossilize and become the major constituent of chalk deposits. Foraminifera are closely associated with sediments, so Vilks classified the sediments of the Lakes and mapped their distribution. From coarse to fine, they ranged from boulders to clay, with fine clays 
being predominant in the deep basins and coarser elements being more common in shallower locations and areas of strong currents, such as the Great Bras d'Or Channel and the Barra Strait. He identified 39 species of foraminifera, groups of which he associated with specific sediment types. The Bras d'Or Lake assemblage was quite different from that of the northern extremity of the Great Bras d'Or Channel and adjacent Sydney Bight. In the Lakes, the most common species was Eggerella advena followed by Trochammina squamata and Milliamina fusca. On the whole, the Lakes' protozoan faunal assemblage was found to be very similar to that seen in St. Margaret's Bay and Mahone Bay, southwest of Halifax. However, E. advena and a less abundant group of foraminifera (Reophacidae) found in the Lakes are common in Arctic inshore waters.

Herring The Bras d'Or Lakes is considered home to at least one population of herring since spawning takes place there in the spring. (By convention, biologists have agreed that the area in which a species spawns will be regarded as its home). Opinions differ as to whether these herring move into the Lakes to spawn and then move out afterwards. Limited returns from a tagging program conducted in Sydney Bight (Sinclair et al., 1980) support this view; three fish tagged in Sydney Bight were captured in Whycocomagh Bay and near Militia Point and a herring tagged in St. Ann's Bay, outside the Lakes, was caught off Pipers Cove in Bras d'Or Lake (Crawford et al., 1982). However, some herring may reside in lakes as they have been caught there during the winter. To further complicate matters, autumn spawning herring have been found (Denny et at 1998); whether this group actually spawns in the lakes is not known. Until 1999 there was a spring fishery targeting the spawning herring; this began after ice break-up and lasted for 3-4 weeks. The main spawning areas were along the western shore of West Bay, Denys Basin, St. Peter's Inlet and off Eskasoni. However, in the last few years of the fishery it was apparent that, with the exception of a limited area near Malagawatch, herring had ceased to spawn south of the Barra Strait and the only egg deposition of note occurred in Baddeck Bay (Denny et al., 1998). In recent years, mackerel, used traditionally as lobster bait, has become expensive; thus the use of cheaper herring as an alternative led to a substantial increase in its demand. The sudden increase in fishing effort on the declining Bras d'Or Lakes stock rapidly brought this herring population to the point of collapse and the fishery was ordered closed in 1999.

Crawford et al. (1982) studied the Bras d'Or Lakes spring-spawning herring in 1980 and 1981. They looked at adult characteristics and carried out egg and larval surveys at a spawning ground in Ross Cove within West Bay. They found that the Lakes herring differed from other herring in a number of characteristics. They were smaller at a given age than Atlantic coast or Northumberland Strait spring-spawners and differed in meristic counts (meristics refers to numbers of physical structures, such as fin rays, gill rakers, and vertebrae, which are useful in differentiating populations). A six year-old Bras d'Or Lakes female herring produced about 47,500 eggs and a nine year-old, about 165,250 . This fecundity was on average about $8 \%$ higher than that of Northumberland Strait spring-spawning herring. Crawford and his team noted spawning in Ross Cove in early April at depths of only $1 / 4 \mathrm{~m}$ to $3 / 4 \mathrm{~m}$; this is one of the shallowest on record for the Atlantic coast. The majority ( $80 \%)$ of eggs were deposited on the eelgrass (Zostera marina) and most of the remainder on sea lettuce (Ulva lactuca). A loss of $85 \%$ of the eggs was estimated and although some eggs were seen to have died, the majority of the reduction was thought to be due mainly to predation by winter flounder and to a lesser extent cod and perhaps even gulls, which were seen to congregate in the area. Herring eggs at Ross Cove began to hatch on April 27 and at peak hatching the density 
of larvae over the spawning bed was over 4,500 per cubic metre of water. The larvae were about $7 \mathrm{~mm}$ long at hatching and grew at a rate of about 1/4 $\mathrm{mm}$ a day.

Seaweed. During the summer of 1970, McLachlan and Edelstein (1971) established 45 sampling stations along the shores of the Bras d'Or Lakes to observe and collect seaweeds. They found that the marine algae were restricted to a narrow band from the shoreline down to 3 to $4 \mathrm{~m}$ depth. A total of 92 species and varieties were identified in their survey; 31 red algae, 31 brown algae, 23 green algae and 7 microscopic blue-green algae. Nowhere was the marine plant cover very dense and much of the bottom was unsuitable for attachment of seaweed, being muddy or made up of other loose material. One species however, which can root in this type of unconsolidated bottom, is the eelgrass, (Zostera marina), which is the most common marine plant in the Lake system. It occurred at all stations and also tended to grow at greater depths than other species. Three algal species were new records for Nova Scotia and one other, found in St. Andrew's Channel, had been only reported from the Sarema and Khiuma Islands in the former Soviet Union.

McLachlan and Edelstein (1971) recognised two seaweed associations in the Lakes; in one, the species were the same as those of the open Atlantic coast of Cape Breton, and in the other, the species were shallow warm-water plants characteristic of protected bays along the Northumberland Strait. The first group, mostly common brown seaweeds, were dominant in the Great Bras d'Or Channel and extended into St. Andrew's Channel, West Bay and the western part of East Bay. These species included the common rockweed or bladder wrack (Fucus vesiculosus), knotweed (Ascophyllum nodusum), kelp (Laminaria agardii), Irish moss (Chondrus crispus) and, similar to Irish moss, the leaf weed (Phyllophora membranifolia). These oceanic species died out as one moved farther into East Bay. In St. Peter's Inlet, the algal flora were sparse and resembled that of the upper reaches of East Bay. Only eelgrass and the whiplike, smooth cord weed, (Chorda filum) were found there. The warm water group of seaweeds were dominant in St. Patrick's Channel, Denys Basin and North Basin. This included sea lettuce (Ulva lactuca), the fern-like Bryopsis hypnoides, twig weed (Ahnfeltia plicata), the coarsely bushy red seaweeds, chenille weed (Dasya pedicellata) and graceful red weed (Gracillaria foliifera) and the finely bushy red seaweeds, banded weed (Ceramium fastigiatum), rough tangle weed (Stilophera rhizodes) and slippery tangle weed (Sphaerotrichia divaricata).

Uncommon morphological forms of some common seaweed species were found in the Lakes. Unusual bushiness, reduction or absence of flotation vesicles and colour variation were some of the anomalies recorded. McLachlan and Edelstein thought the wide range of environmental conditions (temperature, salinity, lack of tides and perhaps low nutrients) in the Lakes might be responsible for these aberrant forms.

\section{Groundfish Trawl Surveys}

Survey methodology 1951-1952. The Fisheries Research Board of Canada investigated the biology of the sealworm (Pseudoterranova decipiens Krabbe) from 1948 to 1953 within the Bras d'Or Lakes. As part of these studies Black (1976) conducted trawl surveys in the Lakes in 1951 (May to the end of December) and 1952 (May to August). He provided no details on the type of fishing gear used other than referring to it as a shrimp trawl. Thirty min tows were made regularly at 3 stations: Baddeck Bay (15 - 20m), Whycocomagh Bay (10 - 30m) and Kempt Head (55 -75m). In addition, a few additional sets were made along the lengths of the Great Bras d'Or and St. Patrick's Channels in June and July of 1952, respectively (Appendix/1). 
Survey methodology 1967. In 1967, the Nova Scotia Department of Fisheries contracted a $40 \mathrm{ft}$ commercial fishing boat to conduct a trawl survey of the Bras d'Or Lakes (MacDonald, 1968). A 3/4 number 35 Yankee trawl was used. The net had mesh of $41 / 2$ in $(11.4 \mathrm{~cm})$ and was fitted with a $11 / 8$ in $(2.8 \mathrm{~cm})$ mesh liner to retain small fish. The trawl headline length was $40 \mathrm{ft}(12.2 \mathrm{~m})$, foot rope length $54 \mathrm{ft}(16.5 \mathrm{~m})$ and height at mouth $7 \mathrm{ft}(2.13 \mathrm{~m})$ (Fig 3). Towing speed was approximately 2.5 knots (4.6 $\mathrm{km}$ per h). Between September 20 and November 16, 117 tows were made throughout most of the Lakes. Towing time varied in length, ranging from 25 to 120 min with an average of $75 \mathrm{~min}$. Set position, depth, type of bottom and weight of fish by species were recorded; number of fish only was given when a particular species was scarce.

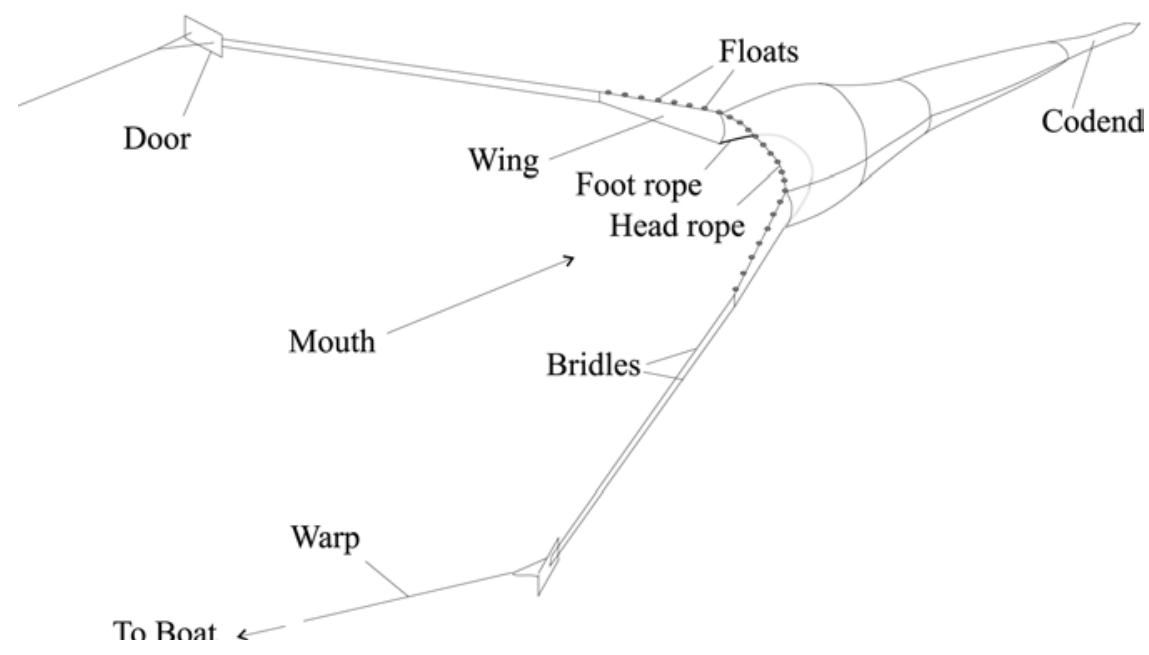

Fig 3 Components of a generalised bottom trawl net.

Survey methodology 1999-2000. In 1999, the EFWC, DFO and the 4Vn Sentinel Fishery Association (4VnSFA), began a cooperative 5 year investigation of the groundfish of the Bras d'Or Lakes. Including trawl, longline and ichthyoplankton surveys, these studies focussed on the biology of cod. Larval, juvenile and adult populations were sampled with a variety of gears. The DFO's 20 m CCGC Navicula carried out bottom trawling for 4 weeks during September and October, and plankton sampling in the late spring. A $4 \mathrm{VnSFA}$ longliner set gear in the Lakes once a month, except when prevented by ice. In addition, a tagging program was started in 2000 to investigate movement of cod within the Lakes and also to determine whether there is exchange of fish between the Lakes and Sydney Bight.

Groundfish were sampled with a small flounder trawl Fig 3. The head rope of the net was $50.5 \mathrm{ft}(15.4 \mathrm{~m}$ ), the foot rope (wire cored rope reinforced with chain) was 59.5 $\mathrm{ft}(18.1 \mathrm{~m})$, the height of the wing at the attachment point to the net is $6 \mathrm{ft}(1.83 \mathrm{~m})$ and the height of the mouth opening of the net, $10 \mathrm{ft}(3.05 \mathrm{~m})$. The main mesh of the trawl was 5 in $(12.7 \mathrm{~cm})$ and the cod-end is equipped with a 1 in $(2.54 \mathrm{~cm})$ mesh liner to retain juvenile fish. The trawl was towed 1 nautical mi $(1.853 \mathrm{~km})$ at a speed of $2.5 \mathrm{knot}(4.6$ 
$\mathrm{km}$ per h), thus the tow duration was approximately $25 \mathrm{~min}$. Total weight, number and length frequencies were recorded for all species of fish. In addition, for cod only, otoliths (ear bones used for ageing the fish) were extracted, maturity determined and stomach contents and fullness assessed. Also, the bottom invertebrate fauna captured by the trawl were identified, counted and weighed (Tremblay, 2002). Water temperature and salinity data were collected with a conductivity / temperature / depth (CTD) profiler.

Comparison of surveys. When comparing the three surveys, several points should be kept in mind. Although year-specific data are available for the 1999/2000 surveys, they were combined and, with one exception, no attempt was made to look at annual variation. This is because the 1967 survey represents 1 y and although Black's (1976) earlier survey represents 2 y of sampling, his data are presented in combined form. Black's survey is limited in geographical extent, whereas the other 2 cover most of the Lakes. On the other hand, Black sampled three seasons, spring to autumn, whereas the later two surveys sampled only the autumn. The 1967 survey (MacDonald, 1968), which extended to mid November, was longer than the 1999/2000 one, which ended in mid October. However, $60 \%$ of the 1967 sets coincided with the time period sampled by the 1999/2000 survey.

A trawl net is towed behind a boat by two cables (warps) which are spooled on two drums of a large winch. These warps are led, one to each side of the boat, through a series of pulleys and then connected to trawl 'doors' (sometimes called otter boards). Each of the doors are attached to bridles, which in turn fasten to the wings of the net (Fig 3). When fishing, the head rope of the net, which is fitted with floats, lifts the top of the net thereby opening its mouth. The foot rope, being longer than the head rope, drags along the bottom in an arc beneath and behind the leading edge of the net; thus the top overhangs the bottom of the net and prevents any upward escape of fish which encounter the foot rope. The trawl doors, angled like kites, spread the mouth of the trawl as they are towed through the water. The width of the mouth of the net is constrained by the length of the head rope (shorter than the foot rope), and its height is a function of the sideways pull of the trawl doors and the upward lift of the floats on the head rope. Based on measurements and mesh size (MacDonald,1968), the trawl net used during the 1967 survey was very similar to the net used in the recent EFWC/DFO surveys.

Fish encountering the wings of a trawl net are herded toward its centre. Thus the effective swept area of the bottom is generally considered to be the distance between the outer ends of the wings multiplied by the distance towed. Unfortunately, MacDonald (1968) does not indicate the length of the wings of the trawl net she used. Therefore, in the following calculations I have assumed that the wings of the trawl nets used in the two surveys were the same and have based any differences on the trawl net body measurements. I estimated the mouth width of the nets by representing the area of the mouth as two back to back right triangles whose angled tops approximate the head rope and whose coincident apexes correspond to the height of the net mouth. Their combined bases form the top of a narrow rectangle beneath, whose span will be equivalent to the width of the net mouth. This distance is easily calculated and indicated that the MacDonald (1968) trawl net mouth width was narrower, and so her trawl would have swept a smaller area than that used in the 1999/2000 surveys. Accordingly, based on net configuration, I have estimated that, over a given distance, the net used in the 1999/2000 surveys would catch about 1.3 times more fish than that used in the 1967 survey. 
MacDonald's (1968) data are expressed as lb per hour. Although the towing speed is listed as 2.5 knots, the actual speed-over-ground (as opposed to boat speed through the water) when towing a net can vary considerably. Maintaining a constant towing speed requires continual monitoring of speed-over-ground (with positioning devices such as GPS) and continual adjustment of boat engine speed to compensate for varying wind, current and trawl net drag (related to degree of bottom roughness). To illustrate, the average time for a one nautical mile tow with CCGC Navicula was 27 min (Std. Dev. $4.3 \mathrm{~min}$ ). The longest duration for this distance was $38 \mathrm{~min}$, and the shortest, 20 min. The 1967 survey boat carried no electronic navigational equipment other than a depth sounder, so an accurate means of determining distance of tow was not possible. To compare with 1999/2000 catch rates, those for the 1967 survey were converted to $\mathrm{kg}$ per tow using tow duration and a towing speed of 2.5 knots and then adjusted by the 1.3 conversion factor. These estimates would be subject to the errors discussed above, and although the calculated value for any specific tow might be inaccurate, the average value for all tows should be reasonable.

Where certain species were scarce in 1967, MacDonald (1968) expressed their quantity by number rather than by weight. For comparison, average individual species weights were calculated using 1999/2000 data: the conversion weights were; windowpane flounder - $210 \mathrm{~g}$, white hake- $201.3 \mathrm{~g}$, and yellowtail flounder - $191.6 \mathrm{~g}$.

\section{Trawl Survey Results}

1951-1952 Black (1976) lists 22 species found during his investigation (Table I). Most common were winter flounder, white hake, Atlantic cod and American plaice;

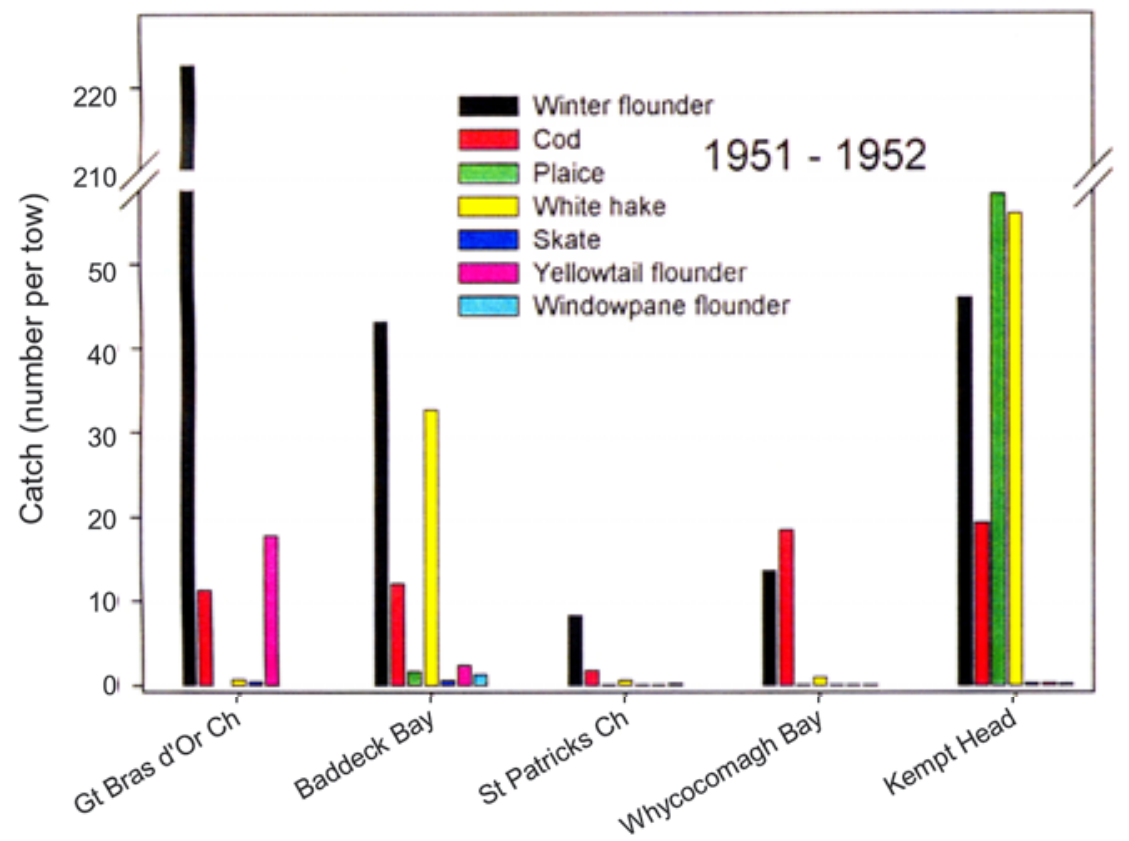

Fig 4 Trawl catch, 1951-1952 by area. 
some of the scarcest were eels, haddock, four-beard rockling, dogfish, and ocean pout. Distribution of some of the more important species in the catch can be found in Fig 4 and Table All. Of the 3 principal sites, Whycocomagh Bay had the lowest overall catch rate and Kempt Head the highest. The highest catch rate was of winter flounder in the Great Bras d'Or Channel in June of 1952. Smelt were quite common in the catch, particularly in shallow areas along St. Patrick's Channel in July of 1952. Although they are not considered a bottom fish and tend to be found swimming nearer the surface, smelt are sufficiently abundant that they are often captured as the net passes through surface layers at the beginning and end of a tow.

Table I Total catch of groundfish taken in the Bras d'Or Lakes, 1951-52. Black (1976).

\begin{tabular}{lr}
\hline Species & Total catch (number) \\
\hline Winter flounder & 7,010 \\
White hake & 4,616 \\
Cod & 2,448 \\
Plaice & 2,247 \\
Smelt & 517 \\
Yellowtail flounder & 307 \\
Cunner & 260 \\
Windowpane flounder & 113 \\
Herring & 70 \\
Mailed sculpin & 70 \\
Skates & 60 \\
Pollock & 59 \\
Longhorn sculpin & 22 \\
Alewife & 19 \\
Eel & 12 \\
Alligatorfish & 7 \\
Spiny dogfish & 5 \\
Sea raven & 5 \\
Shorthorn sculpin & 3 \\
Fourbeard rockling & 3 \\
Haddock & 2 \\
Ocean pout & 2 \\
\hline
\end{tabular}

Black noted seasonal changes in the distribution of fish that he thought might be related to temperature. Cod and plaice numbers diminished with increasing bottom temperature in Baddeck Bay during the summer and while abundant at the deeper Kempt Head station during the summer, diminished there during the winter and early spring. Black suggested a movement from the deeper area to a shallower one, perhaps Baddeck Bay, where temperature might be more suitable for these species. He also noted seasonal changes in abundance of white hake, cunner and winter flounder. Hake apparently moved away from the deeper, Kempt Head station to the shallower, Baddeck Bay station in the late summer and autumn. The number of cunner and winter flounder increased rapidly in Baddeck Bay with increasing bottom water temperature. In the case of winter flounder, the increase was mainly in smaller size-classes. Black noted that the length frequency of white hake also changed in favour of smaller fish during autumn.

1967 MacDonald (1968) found a total of 18 species of fish with American plaice, winter flounder and Atlantic cod being the most abundant (Table II, Fig 5). As Black had found, eels, four-beard rockling, and pout were rare. However, haddock and 
dogfish that were scarce in 1951/52 were not caught at all. Pollock, which had appeared in moderately low numbers only at the Kempt Head station, were absent.

Table II Total catch of groundfish taken in the Bras d'Or Lakes, 1967. MacDonald (1968).

\begin{tabular}{lr}
\hline Species & Total catch $(\mathrm{kg})$ \\
\hline Plaice & 3,334 \\
Winter flounder & 3,008 \\
Cod & 2,756 \\
Skate & 145 \\
Yellowtail & 86 \\
Smelt & 40 \\
White hake & 15 \\
Windowpane flounder & $* 14(67)$ \\
Sculpins & $* 10(32)$ \\
Perch (probably Cunner) & 10 \\
Witch flounder & $* 6(10)$ \\
Herring & 1 \\
Gaspareau & 1 \\
Dollarfish & $<1$ \\
Eel & $<1$ \\
Eel-pout & $<1$ \\
Four-beard rockling & $<1$ \\
Silverside & $<1$ \\
\hline
\end{tabular}

* Estimated weight based on number of fish (in brackets) reported.

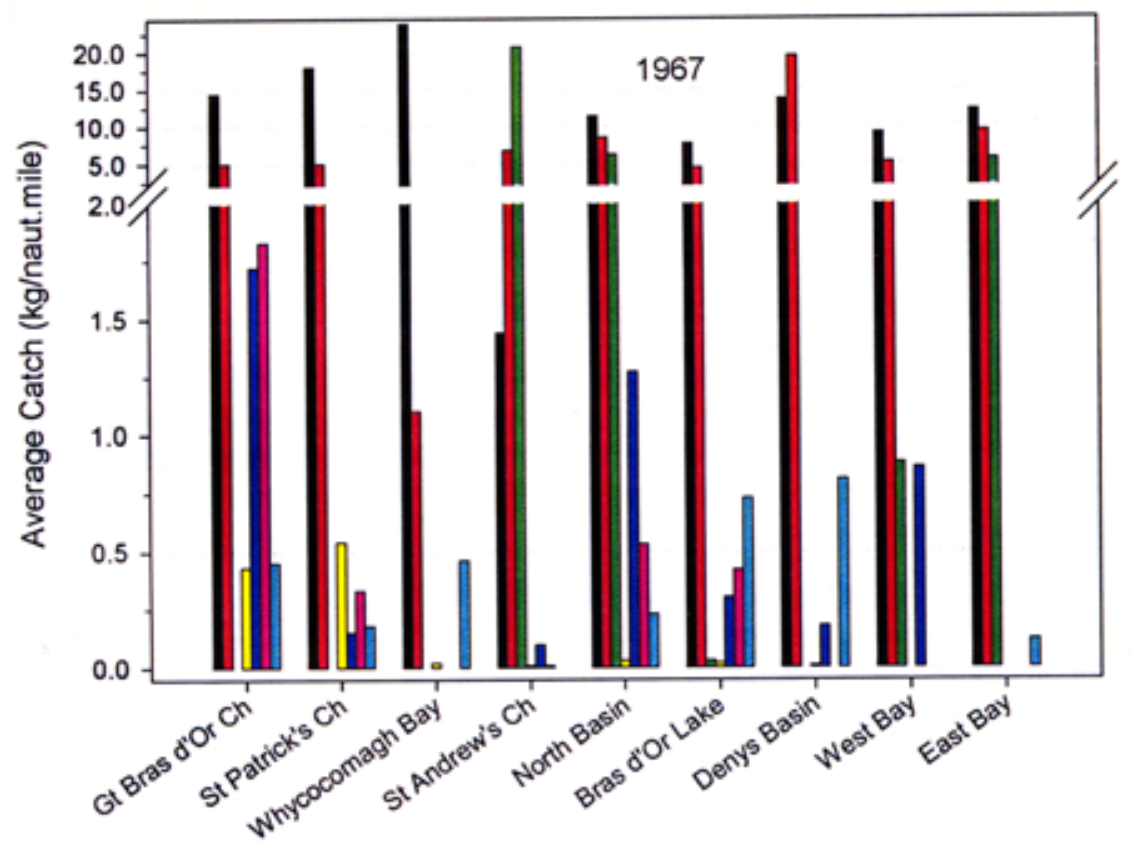

Fig 5 Trawl catch, 1967 by area. Legend for Fig 4 also applies to this Fig. 
1999/2000 Surveys A total of 25 species were taken in these surveys, the most abundant being winter flounder and Atlantic cod (Table III, Fig 6). The most noticeable difference between this survey and those of earlier years was the large decrease in the number of American plaice. Eels, pollock, haddock, dogfish and pout, present in the two earlier survey periods, were not caught. Smelt, as in earlier surveys, continued to be a common part of the catch and also, as previously, were found in abundance in St. Patrick's Channel. Smelt spawn in fresh water, therefore, it is not surprising to find them in this Channel as it receives most of the fresh water entering the Lakes.

Table III. Total catch of groundfish taken in the Bras d'Or Lakes, 1999/2000

\begin{tabular}{lr}
\hline Species & Total catch $(\mathrm{kg})$ \\
\hline Winter flounder & $1,509.1$ \\
Cod & $1,296.1$ \\
White hake & 195.1 \\
Winter skate & 100.3 \\
Windowpane flounder & 85.6 \\
Plaice & 49.9 \\
White perch & 34.9 \\
Longhorn sculpin & 19.1 \\
Yellowtail flounder & 12.5 \\
Smelt & 12.5 \\
Little skate & 8.8 \\
Thorny skate & 6.9 \\
Cunner & 6.4 \\
Shorthorn sculpin & 6.2 \\
Sea raven & 3.3 \\
Witch flounder & 0.6 \\
Gaspareau & 0.5 \\
Herring & 0.2 \\
Dollarfish & 0.1 \\
Silver hake & $<0.1$ \\
Silverside & $<0.1$ \\
Mailed sculpin & $<0.1$ \\
Alligator fish & $<0.1$ \\
Flying gurnard & $<0.1$ \\
Atlantic moonfish & $<0.1$ \\
\hline
\end{tabular}

A total of 46 species of fish has been recorded for the Bras d'Or Lakes (Table IV). Most, like cod, are resident, while others such as mackerel, are regular visitors making seasonal trips into the Lakes. Still others, stray into the Lakes on an irregular basis; these are considered vagrants, individuals that have wandered from their normal range and are present because of usually warm conditions in the Atlantic outside the Lakes. This often occurs in the late summer or early autumn when exotic visitors are transported northwards by the Gulf Stream. Not only do foreign fish species like the sunfish, Mola mola; flying gurnard, Dactylopterus volitans; and dollarfish, Poronotus triacanthus reach Nova Scotia shores in this way, but also other creatures such as sea turtles.

Distribution. There appears to be little difference in the geographical distribution of groundfish as documented by the 1967 and 1999/2000 surveys. Therefore, the distribution of fish in the more densely sampled 1967 survey is provided for illustration (Fig $7 \mathrm{a}, \mathrm{b}$ ). 
Table IV Species list and status of fish reported from the Bras d'Or Lakes.

\begin{tabular}{|c|c|c|c|c|}
\hline Common Name & Scientific Name & Status & Reported & Captured \\
\hline Atlantic cod & Gadus morhua & $\mathrm{C}$ & $\mathrm{B}, \mathrm{M}, \mathrm{L}$ & $\mathrm{T}, \mathrm{P}$ \\
\hline Atlantic moonfish & Vomer setapinnis & $\mathrm{R}(\mathrm{v})$ & $\mathrm{L}$ & $\mathrm{T}$ \\
\hline Atlantic salmon ${ }_{1}$ & Salmo salar & $\mathrm{R}$ & $B, L$ & $\mathrm{H}$ \\
\hline Alligatorfish & Aspidophoroides monopterygius & $\mathrm{R}$ & $B, L$ & $\mathrm{~T}$ \\
\hline American plaice & Hippoglossoides platessoides & L & $\mathrm{B}, \mathrm{M}, \mathrm{L}$ & $\mathrm{T}$ \\
\hline Blueback herring & Alosa aestivalis & $\mathrm{L}$ & $\mathrm{D}$ & $\operatorname{Tr}$ \\
\hline Brook trout & Salvelinus fontinalis & $\mathrm{R}$ & B & $\mathrm{H}$ \\
\hline Cunner & Tautogolabrus adspersus & $\mathrm{C}$ & $B, M, L$ & $\mathrm{~T}, \mathrm{P}$ \\
\hline Daubed shanny & Lumpenus maculatus & $\mathrm{L}$ & $\mathrm{L}$ & $\mathrm{P}$ \\
\hline Dollarfish (butterfish) & Poronotus triacanthus & $\mathrm{R}(\mathrm{v})$ & $\mathrm{M}, \mathrm{L}$ & T \\
\hline Eel & Anguilla rostrata & $\mathrm{L}$ & $B, M$ & $\mathrm{~T}$ \\
\hline Eelpout & & $\mathrm{R}$ & M & $\mathrm{T}$ \\
\hline Flying gurnard & Dactylopterus volitans & $\mathrm{R}(\mathrm{v})$ & L & $\mathrm{T}$ \\
\hline Fourbeard rockling & Enchelyopus cimbrius & $\mathrm{C}$ & $\mathrm{B}, \mathrm{M}, \mathrm{L}$ & $\mathrm{T}, \mathrm{P}$ \\
\hline Gaspareau (alewife) & Alosa pseudoharengus & $\mathrm{C}(\mathrm{m})$ & $B, M, L$ & $\mathrm{~T}$ \\
\hline Greenland $\operatorname{cod}_{2}$ & Gadus ogac & $\mathrm{R}$ & $\mathrm{L}$ & $\mathrm{H}$ \\
\hline Haddock 2 & Melanogrammus aegelfinus & $\mathrm{R}$ & B & $\mathrm{T}$ \\
\hline Herring & Clupea harengus & $\mathrm{L}(\mathrm{m})$ & $\mathrm{B}, \mathrm{M}, \mathrm{L}$ & $\mathrm{T}, \mathrm{P}$ \\
\hline Little skate & Raja erinacea & $\mathrm{R}$ & $\mathrm{L}$ & $\mathrm{T}$ \\
\hline Longhorn sculpin & Myохосерhalus octodecemspinus & M & $B, L$ & T,P \\
\hline Mackerel & Scomber scombrus & $\mathrm{C}(\mathrm{m})$ & $\mathrm{L}$ & $\mathrm{P}, \mathrm{H}$ \\
\hline Mailed sculpin & Triglops murrayi & $\mathrm{R}$ & $B, L$ & $\mathrm{~T}$ \\
\hline Ocean pout & Macrozoarces americanus & $\mathrm{R}$ & B & T \\
\hline Pipefish & Sygnathus fuscus & M & $\mathrm{D}$ & B \\
\hline Pollock & Pollachius virens & $\mathrm{R}$ & B & $\mathrm{T}$ \\
\hline Rainbow trout $_{3}$ & Salmo gairdneri & $\mathrm{L}$ & $\mathrm{B}, \mathrm{L}$ & $\mathrm{H}$ \\
\hline Rock gunnel & Pholis gunnellis & $\mathrm{L}$ & $\mathrm{L}$ & $\mathrm{P}$ \\
\hline Sculpins & & $\mathrm{L}$ & M & T \\
\hline Sea raven & Hemitripterus americanus & $\mathrm{L}$ & $B, L$ & T \\
\hline Shorthorn sculpin & Mуохосерhalus scorpius & $\mathrm{L}$ & $\mathrm{B}, \mathrm{L}$ & T \\
\hline Silver hake & Merluccius bilinearis & $\mathrm{R}$ & $\mathrm{L}$ & T \\
\hline Silverside & Menidia menidia & M & $L, M$ & $\mathrm{~T}$ \\
\hline Skate & & M & $B, M$ & T \\
\hline Smelt & Osmerus mordax & $\mathrm{C}$ & $B, M, L$ & $\mathrm{~T}, \mathrm{P}$ \\
\hline Spiny dogfish & Squalus acanthius & $\mathrm{R}(\mathrm{m})$ & B & $\mathrm{T}$ \\
\hline Snake blenny & Lumpenus lumpaetiformis & $\mathrm{L}$ & $B, L$ & $\mathrm{P}$ \\
\hline Sunfish & Mola mola & $\mathrm{R}(\mathrm{v})$ & $B, L$ & W \\
\hline Thorny skate & Raja radiata & $\mathrm{L}$ & $\mathrm{L}$ & $\mathrm{T}$ \\
\hline Three-spined stickleback & Gasterosteus aculeatus & $\mathrm{C}$ & $\mathrm{L}$ & $\mathrm{T}_{4}$ \\
\hline White hake & Urophycis tenuis & M & $\mathrm{B}, \mathrm{M}, \mathrm{L}$ & $\mathrm{T}, \mathrm{P}$ \\
\hline White perch & Roccus americanus & $M(m)$ & $\mathrm{L}$ & $\mathrm{T}$ \\
\hline Windowpane flounder (brill) & Scophthalmus aquosus & $\mathrm{L}$ & $\mathrm{B}, \mathrm{M}, \mathrm{L}$ & $\mathrm{T}, \mathrm{P}$ \\
\hline Winter flounder (blackback) & Pseudopleuronectes americanus & C & $\mathrm{B}, \mathrm{M}, \mathrm{L}$ & $\mathrm{T}, \mathrm{P}$ \\
\hline Winter skate & Raja ocellata & M & $\mathrm{L}$ & $\mathrm{T}$ \\
\hline Witch flounder (grey sole) & Glyptocephalus cynoglossus & $\mathrm{R}$ & $M, L$ & $\mathrm{~T}$ \\
\hline Yellowtail flounder & Limanda ferruginea & M & $B, M, L$ & T \\
\hline
\end{tabular}

1 Wild salmon very rare but farmed salmon occasionally fairly common after escapes from pens.

2 Taken by longline (4VnSFA), recently in Sept. 2001 by bottom trawl and recorded by Scott (1952)

${ }^{3}$ Stocked in the lakes by NS Department of Fisheries in the past; also farmed and common after escapes.

${ }^{4}$ Often in stomachs of cod.

Status: C - common; M - medium abundance; L - low abundance; $\mathrm{R}$ - rare; $\mathrm{v}$ - vagrant, $\mathrm{m}$ - migratory Reported: B - Black (1976); M - MacDonald (1967); L - Lambert (present study); D - Denny (2001) Captured: $\mathrm{T}$ - trawl; P - plankton net; $\mathrm{B}$ - beach seine; $\mathrm{Tr}$ - trap; $\mathrm{H}$ - hook\&line; $\mathrm{W}$ - washed ashore 


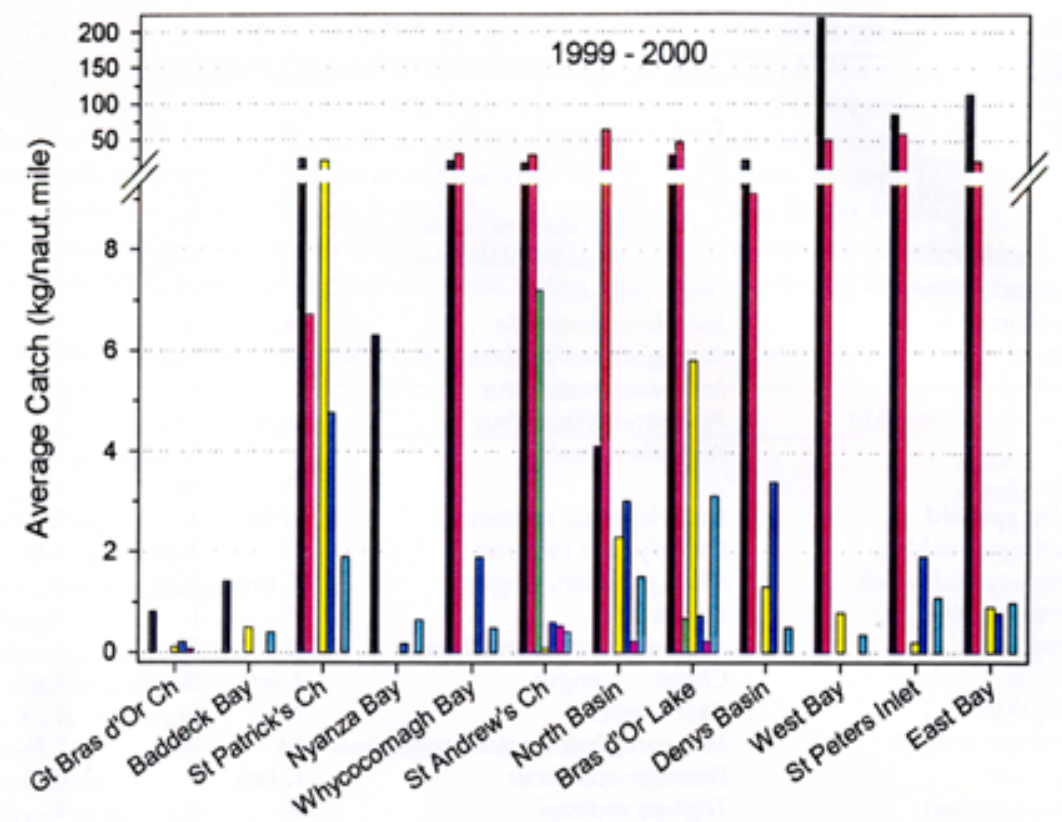

Fig 6 Trawl catch, 1999-2000 by area. Legend for Fig 4 also applies to this Fig..

Of the 8 species shown, the most common, winter flounder, was found at all trawl locations throughout the Lakes (Fig 4-6). Cod were caught at most locations and windowpane flounder, white hake and winter skate, although not plentiful, were also widespread. The most common skate found in the 1999/2000 surveys was the winter skate. Whereas, skates were not specified in earlier surveys, most were likely winter skate, since they were caught in fairly shallow water, where they tend to dominate. Plaice were fairly widespread in 1967, but confined to deep areas of St. Andrew's Channel and Bras d'Or Lake in 1999/2000. In both surveys the distribution of yellowtail flounder was limited to North Basin and a small area of Bras d'Or Lake off Pipers Cove. The distribution of witch flounder was also unchanged and restricted to the deep trench of St. Andrew's Channel.

Depth appeared to be important in determining the distribution of some species, but less so with others (TableV). During the 1999/2000 survey, which fished over the greatest depth range, most winter skate, yellowtail flounder and winter flounder were found in water $21 \mathrm{~m}$ or less. The majority of white hake, windowpane flounder and cod were caught between 29 and $45 \mathrm{~m}$ and most plaice and witch flounder occurred in water below $150 \mathrm{~m}$. Witch flounder, yellowtail flounder and probably winter skate had the narrowest range of depth distribution, whereas the other major species occurred over many depths. Although the other two surveys fished at shallower depths (1951/1952,10-75m and 1967, 5.5-106 m), and the earlier survey had a seasonal component, similar trends are evident. 

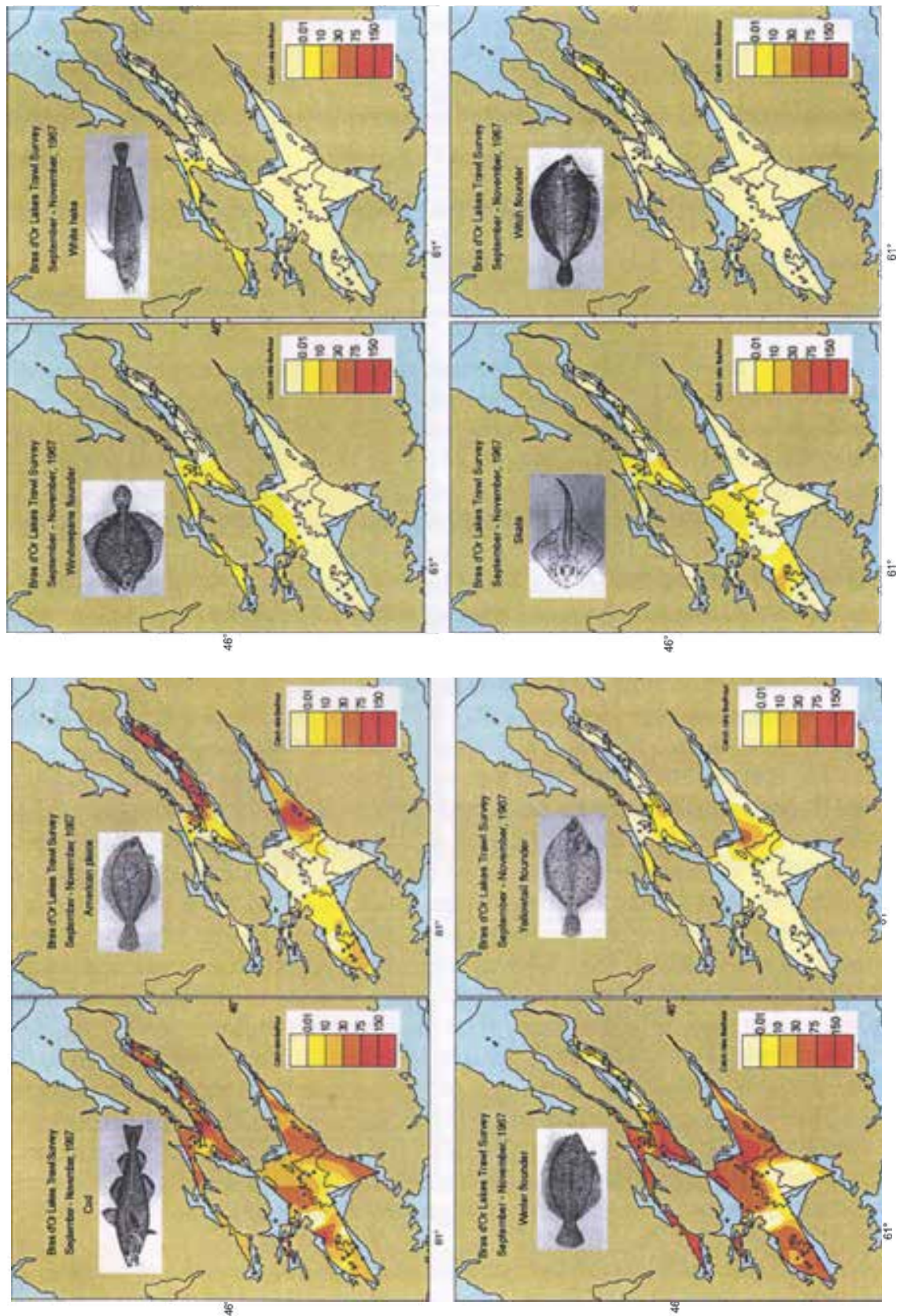

Fig 7 Distribution of major fish species from 1967 survey. (a) cod, plaice, winter flounder and yellowtail flounder; (b) windowpane flounder, white hake, skate and witch flounder. 
TableV Distribution of selected species by depth $(\mathrm{m})$ by survey. Average value is weighted by catch.

\begin{tabular}{lccccccc}
\hline & \multicolumn{2}{c}{ Minimum } & \multicolumn{2}{c}{ Maximum } & \multicolumn{3}{c}{ WeightedAverage } \\
Species & $99 / 00$ & 1967 & $99 / 00$ & 1967 & $99 / 00$ & 1967 & $51 / 52$ \\
\hline Winter skate* & 7 & 5 & 27 & 73 & 18 & 25 & 25 \\
Winter flounder & 7 & 5 & 260 & 82 & 19 & 26 & 32 \\
Yellowtail flounder & 10 & 15 & 27 & 37 & 21 & 23 & 20 \\
White hake & 9 & 5 & 134 & 40 & 29 & 22 & 38 \\
Windowpane flounder & 7 & 5 & 125 & 59 & 31 & 15 & 20 \\
Cod & 7 & 5 & 260 & 92 & 45 & 32 & 32 \\
Plaice & 20 & 18 & 263 & 92 & 169 & 53 & 62 \\
Witch flounder & 260 & 40 & 260 & 55 & 260 & 51 & - \\
\hline
\end{tabular}

* Assumed to be the predominant species for pre-1999 surveys that specified only "Skate".

Abundance. Some interesting differences are evident in the findings of the trawl surveys conducted during the 3 survey periods. The most noticeable are changes in the relative abundance of species within each survey period (Fig 8). Whereas little change is evident for winter flounder and cod, which dominate the catch in all surveys, American plaice, which in earlier years were common, now form a minor fraction of the total catch. White hake made up a substantial proportion of the catch in 1951/1952, were very scarce in 1967, but increased in 1999/2000 catches. However, the high numbers of hake in 1951/1952 could be due to a geographical bias, since they were seen in later surveys to be more common in the north-west of the Lakes, where most of Black's (1976) fishing sets were located.

In 1999/2000 catches made in the Great Bras d'Or Channel and Baddeck Bay were noticeably lower than other locations (Fig 6). However, catches from the earlier surveys in these same two regions were not substantially lower than in other areas of the Lakes (Fig 4, 5). In 1951/1952 both these areas produced a good catch, dominated by winter flounder. In fact, the Great Bras d'Or Channel, with only 6 tows, yielded almost as many winter flounder as 36 tows off Kempt Head. Baddeck Bay was not sampled in 1967, but tows were made in the Great Bras d'Or Channel and produced an amount of fish slightly less than the average for all sites (Fig 5). In 1999/2000 only one set was made in each of the two areas in question with few fish caught. Bottom temperature at the Baddeck Bay site was high, which would be the reason for the scarcity of cod and possibly other species; whereas, Black's 1951/1952 survey fished during the spring and early summer when bottom temperatures would be more acceptable to cod. The one set in the Great Bras d'Or Channel in 1999 was made just inside the entrance to the Lakes; whereas, in 1951/1952, tows were made along the entire length of the Channel. In 1967, most of the fishing sets were made at the southern end of the Channel close to North Basin (Fig 7). Thus the differences in fish abundance in the Channel between the 1999 and earlier surveys are probably related to differences in tow location, more so than indicative of a general change in abundance within the Channel.

When catch rates are standardised to kg per nautical mile, the data show that, on average, fish seem to be about three times more abundant in 1999/2000 than in1967 (Fig 5, 6; Tables AIII, AIV). Catches in East Bay and West Bay in particular, appear to have increased by about 5-10 times; most of this is appears to be due to an increase in the number of winter flounder. Although the net used by the 1999/2000 survey probably catches more (approx. 1/3 more over a given distance) than that used in 
the 1967 survey, it seems improbable that such large increases can be attributed to differences in trawl gear alone. A more accurate estimation of catch rates of the more common species was attempted by accounting for differences in gear efficiency (see earlier section on comparison of surveys). For most species, the differences in the recalculated catch rates appear large enough to be real (TableVI). Cod, winter flounder and white hake seem to have increased in abundance and American plaice decreased. Little change was indicated in the case of yellowtail flounder and winter skate.
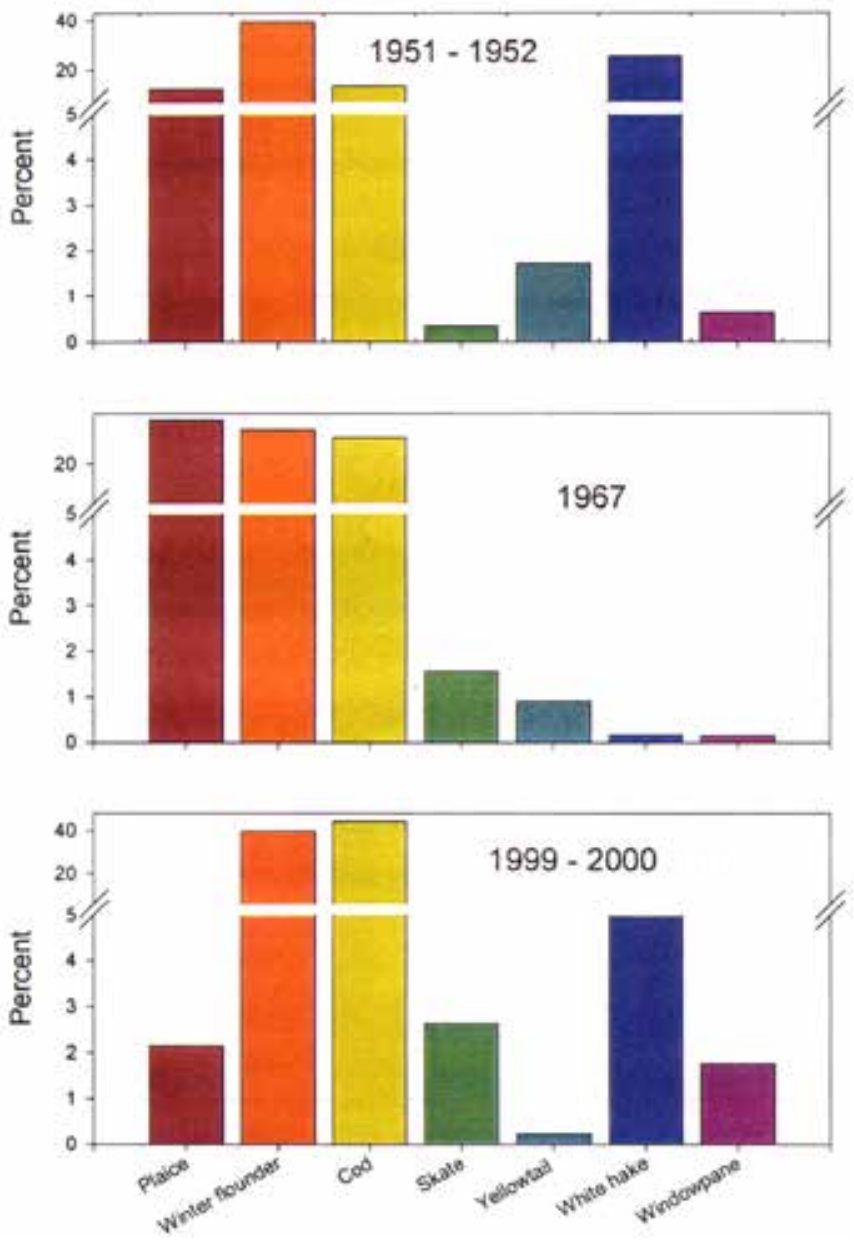

Fig 8 Relative abundance of fish species in the Bras d'Or Lakes between surveys. 
Table VI Comparison of catch rate (kg/naut.mile) of some Bras d'Or Lakes' groundfish species between two survey periods. The 1967 data have been multiplied by 1.3 to compensate for gear differences from the 1999/2000 surveys.

\begin{tabular}{lrr}
\hline Species & 1967 & $1999 / 2000$ \\
\hline Winter flounder & 11.9 & 39.8 \\
Cod & 10.0 & 34.2 \\
Plaice & 9.9 & 1.1 \\
Yellowtail flounder & 0.4 & 0.2 \\
Skate & 0.7 & 1.5 \\
White hake & 0.1 & 3.5 \\
\hline
\end{tabular}

Length frequency. In 1999/2000, fish lengths were measured and length-frequency plots constructed for 6 of the most abundant species (>95\% of total biomass caught). Length data were segregated by year when abundance warranted it, and combined when numbers were too few (Fig 9a-e). Data for fish from Sydney Bight to the Gulf of Maine (Table VII) from Bigelow and Shroeder (1953), Beacham (1982 and 1983a,b), Leim and Scott (1966), and O'Brien et al. (1993) allow interpretation of the information provided in Fig 9. Assuming that Bras d'Or Lakes fish do not differ substantially from those within the geographical range of Table VII, only cod, winter flounder and windowpane flounder had clear representation as mature adults, juveniles and youngof-the-year (0-group). Very few of the white hake could be considered mature as only about six of the 501 collected were $40 \mathrm{~cm}$ or greater in length. Most of the hake were juveniles with a few 0-group taken in 1999. All of the plaice were probably mature adults. Yellowtail flounder were scarce and mostly adults with a few juveniles.

Table VII Threshold lengths at different life stages for selected species.

\begin{tabular}{lcc}
\hline Species & Length at 1 year $(\mathrm{cm})$ & Length at maturity $(\mathrm{cm})$ \\
\hline Cod & $10-15$ & $30-40$ \\
Winter flounder & $10-15$ & $25-30$ \\
White hake & $15-20$ & $40-50$ \\
Windowpane flounder & $10-12$ & $22-25$ \\
Yellowtail flounder & $12-14$ & $25-30$ \\
Plaice & $7-8$ & $20-40$ \\
\hline
\end{tabular}

Clear growth patterns are present in the cod length frequency plots, as year-class modes can be traced from one year to the next. 0-group cod, about 7 months old at the time of survey if spawned in early March, appear as a mode at $8 \mathrm{~cm}$ in 1999 (Fig 9a). The year 2000 plot shows this group (now 1 year and 7 months old) as a second mode at about $18 \mathrm{~cm}$. The number of 0-group fish was about three times greater in 1999 (1999 year-class) than in 2000 implying that more young cod were born in the spring of 1999 (assuming juvenile survival was the same in both years). In comparison to 2000, few cod around $18 \mathrm{~cm}$ were caught in 1999. This suggests that relatively few cod were hatched in 1998, unless of course, there was high mortality of yearling cod sometime during the year following spawning. Thus it appears the 1999 year-class was better than either of the year before or the year after.

During the recent surveys, and in particular 1999, the number of small white hake was striking Fig 9d. Length frequency data indicate an interesting geographical trend in size. The average length of hake increases from $14.4 \mathrm{~cm}$ in the Great Bras d'Or Channel, to $23.5 \mathrm{~cm}$ within areas north of the Barra Strait, to $26.8 \mathrm{~cm}$ south of the Strait (Table VIII). 

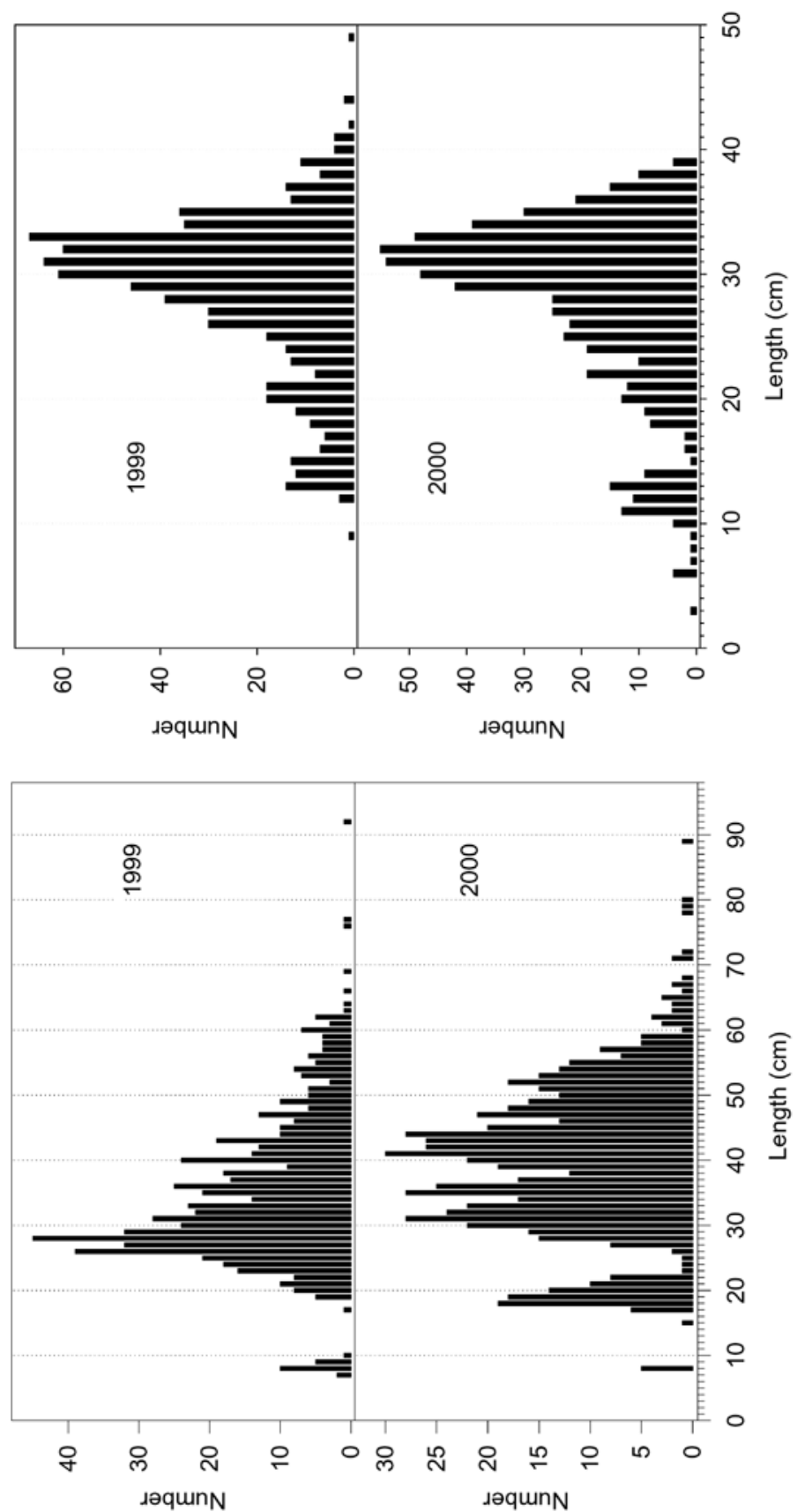

Fig 9 Length frequencies of selected Bras d'Or Lakes groundfish from trawl samples taken in 1999 and 2000; (a) cod, (b) winter flounder, (c) windowpane flounder, (d) white hake, (e) American plaice and yellowtail flounder [data combined for 1999 and 2000] 

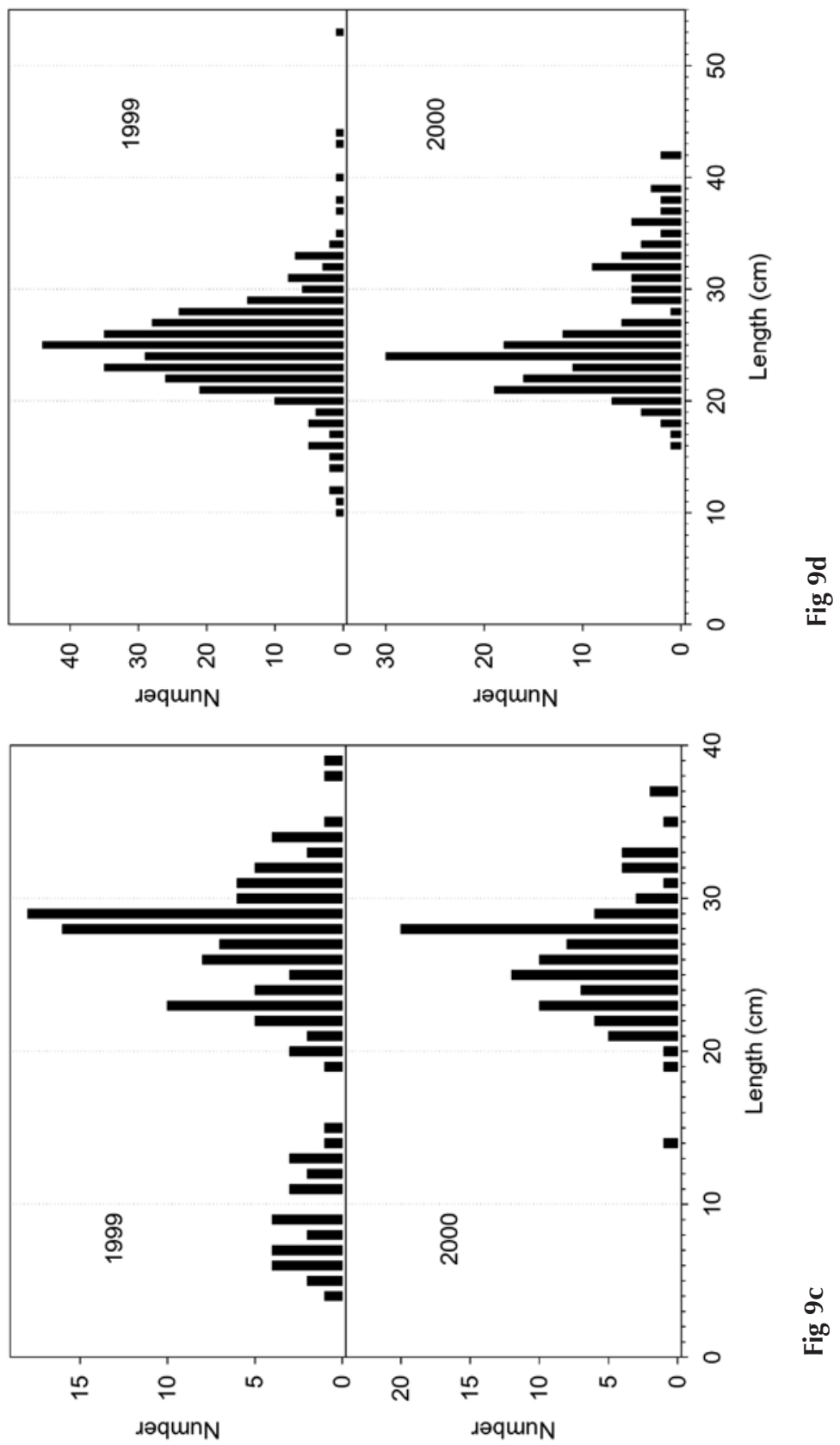

Fig 9 cont'd 


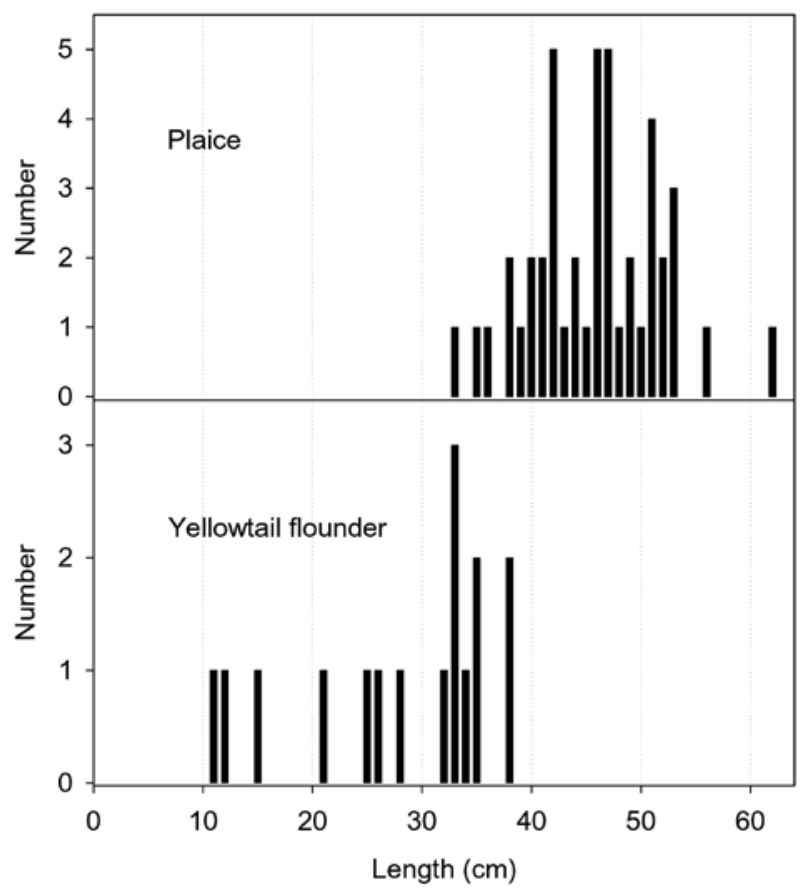

Fig 9e

Fig 9 cont'd

Table VIII Weighted average length of white hake by area of the Bras d'Or Lakes, 1999-2000.

\begin{tabular}{lc}
\hline Location & Wt. Average length $(\mathrm{cm})$ \\
\hline Great Bras d'Or Channel & 14.4 \\
Baddeck Bay & 21.8 \\
St. Andrew's Channel & 23.5 \\
Entrance Denys Basin & 23.7 \\
St. Patrick's Channel & 23.9 \\
North Basin & 24.9 \\
St. Peter's Inlet & 25.3 \\
East Bay & 26.8 \\
Bras d'Or Lake & 28.9 \\
West Bay & 29.3 \\
\hline
\end{tabular}

Cod - The case for resident populations. Are the cod in the Bras d'Or Lakes part of the Sydney Bight cod population or are they a separate stock? Certainly many cod in the Lakes look different from Sydney Bight cod, often having a different colouration. However, colour is variable within any cod population. Many Bras d'Or Lake cod are heavily infested by a parasitic worm, often to the extent they appear emaciated. Unfortunately, as with colouration, there is too much variability in this characteristic for it to be a reliable indicator of population affinity. More convincing are results from plankton sampling which reveal that cod spawn in the Bras d'Or Lakes. This spawning, 
most of which occurs in St. Andrew's Channel and East Bay, is at least a month earlier than in adjacent Sydney Bight, where cod spawn in late April and May, suggesting that the cod in the Lakes are a different stock. This was confirmed by studies that showed distinct genetic differences between Bras d'Or Lakes and Scotian Shelf cod (Pogson et al., 2001). In addition, laboratory testing revealed physiological differences between Lakes cod and their Scotian Shelf counterparts (Nelson et al, 1994 \& 1996). In these tests, cod were made to swim against a current in a 'swim tunnel' while their blood chemistry was monitored. The temperature and salinity of the water circulating in this tunnel were then varied and the length of time until the fish tired was measured. The Bras d'Or Lakes cod were found to be more adaptable to changing conditions than were their 'open-ocean' cousins.

Evidence in the form of parasite prevalence suggests strongly that another distinct stock of cod resides in Whycocomagh Bay. Many cod in the Bras d'Or Lakes are heavily infested with the sealworm (Pseudoterranova decipiens Krabbe). However, the cod inhabiting Whycocomagh Bay harbour very few of these parasites. Black (1976) quantified the incidence of worms in cod at 3 locations (Table IX); the lower rates of worm infestation in Whycocomagh are clear. Only $10 \%$ to $20 \%$ of young cod carried worms despite the fact that Whycocomagh Bay is adjacent to St. Patrick's Channel where over $80 \%$ of young cod were infested (Scott and Black, 1960).

Table IX Average number of Pseudoterranova decipiens per cod at three locations in the Bras d'Or Lakes (Black, 1976).

\begin{tabular}{lrrrrrr}
\multicolumn{2}{r}{ Baddeck Bay } & \multicolumn{3}{c}{ Kempt Head } & \multicolumn{3}{c}{ Whycocomagh Bay } \\
\hline Age (y) & 1950 & 1951 & 1950 & 1951 & 1950 & 1951 \\
\hline 1 & 2.3 & 3.1 & 5.4 & 2.5 & 0.1 & 0.1 \\
2 & 11.0 & 9.9 & 8.3 & 8.9 & 0.3 & 0.3 \\
3 & 9.7 & 17.7 & 16.0 & 12.8 & 0.0 & 0.3 \\
4 & 11.9 & 13.9 & 14.6 & 16.2 & 0.5 & 0.4 \\
5 & 15.2 & 20.3 & 16.8 & 21.5 & 1.3 & 1.7 \\
6 & 31.4 & 26.2 & & 27.9 & 1.3 & 2.0 \\
7 & 34.1 & 30.1 & & 37.9 & 4.3 & 3.2 \\
\hline
\end{tabular}

The worm has a complex life cycle which requires a number of hosts. The adult worm resides in the intestines of the seal and its eggs are shed along with the faeces of the seal. Grey seals (Halichoerus grypus) are heavily infested, harbour seals (Phoca vitulina) carry much lower worm burdens, and harp seals (Phoca groenlandia) are rarely infested (Brattey and Stobo, 1990). The microscopic eggs (approx. $0.04 \mathrm{~mm}$ diameter) settle to the bottom and hatch into tiny worm-like larvae about $0.2 \mathrm{~mm}$ in length (Bratty, 1990). The larvae attach themselves by their tails to the substrate where their 'wiggling' motion attracts small benthic copepods (Fig 2) which consume the larval parasite. Within the body cavity of the copepod, the parasite grows to about 0.5 $\mathrm{mm}$ at which size it is too small to be able to infect a fish. Further growth occurs after transmission to larger invertebrates which prey on the copepod. The hosts at this stage include amphipods, mysids, sand shrimps, nudibranchs (sea slugs) and polychaete worms (McLelland, 1990). The larval worm grows to $2 \mathrm{~mm}$ or more within these larger hosts at which point it is capable of surviving the digestive process of a fish and penetrating the wall of its intestine (McLelland et al., 1983). The parasite can be transmitted to a wide range of fish; some such as smelts, pouts, sculpins and flounders, which eat infected invertebrates and others, such as cod and white hake, which consume both invertebrates and other infected fish (McLelland et al. 1990). Thus the 
transmission path of $P$. decipiens through successive hosts is not simple and direct; it is a network of interconnecting paths leading to a myriad of alternate hosts. Successively larger hosts allow the larval parasite to grow until finally, when its intermediate fish host falls prey to a seal, it is large enough to establish residence in the stomach and digestive tract of the seal where it grows to sexual maturity.

It is uncertain whether the number of seals in the Bras d'Or Lakes relative to numbers in the Atlantic coastal region outside the Lakes is high or low. Scott and Black (1960) showed that both harbour seals and grey seals in the Bras d'Or Lakes were carriers of adult $P$. decipiens ( the average number in their stomachs was 250 and 1500, respectively). They report that seals frequent the Lakes in winter but are scarce in the summer; highest reported sitings were between Baddeck Bay and Grand Narrows. It is clear that seals in the Lakes have a greater worm load than those outside. In a summary which compares a number of seal investigations, Brattey and Stobo (1990) indicated that 3 grey seals that were autopsied by Scott and Fisher (1958) had an average worm load 5 times greater than seals from eastern Cape Breton outside the Lakes. The mean numbers of adult and larval parasites found in these seals in the Lake were 169 and 2727, respectively.

A distinguishing feature of Whycocomagh Bay is the low level of oxygen in deep basins at each end of the Bay; the western one being completely anoxic (Petrie and Bugden, 2002; Strain and Yeats, 2002). Cod avoid these areas of low oxygen and aggregate at intermediate and shallow depths within the Bay. Due to this lack of oxygen over a large area of the bottom of the Bay, benthic organisms other than some microorganisms could not survive. Thus many of the intermediate invertebrate hosts of the cod worm such as marine worms, amphipods and mysid shrimps would be scarce or absent. Scott and Black (1960) have reported low abundance of mysids in Whycocomagh Bay. In the absence of intermediate invertebrate hosts, the parasite would not be able to complete its life cycle. Furthermore, Scott and Black (1960) report that seals were rarely seen in Whycocomagh Bay. Therefore, the low level of parasites seen in the cod of the Bay may be due to both the scarcity of primary (seals) and intermediate (benthic invertebrate) hosts. It follows that there must be little movement of cod out of Whycocomagh Bay, and conversely, few fish can be moving into the Bay from St. Patrick's Channel where infestations are high. Possibly this is due to the restricted passageway at Little Narrows, which may discourage the movement of cod between the Bay and St. Patrick's Channel (Black, 1976).

Cod in many parts of the north Atlantic are known to undergo extensive migrations related to feeding, spawning and overwintering. The cod of the Gulf of St Lawrence spend about half the year inside the Gulf and the remainder outside in Sydney Bight. After spawning in the Gulf during June, they feed throughout the summer before forming large aggregations in October prior to moving east to deep water in Cabot Strait off Sydney Bight to avoid subzero water temperatures that are prevalent in many areas of the Gulf of St. Lawrence during winter. In late April and May, the cod return to the Gulf to spawn and begin the cycle anew. Other cod stocks on the northeast coast of Nova Scotia, including the resident Sydney Bight stock, also undergo similar migrations, but to a much lesser extent. They inhabit coastal waters during the summer months but then move to deeper, offshore waters during the winter to avoid cold water on the shallow coastal banks.

What of the cod in the Bras d'Or Lakes? Although most evidence seems to indicate that most cod in the Lakes do not venture into Sydney Bight, it is largely circumstantial and qualitative. As mentioned previously, differences in appearance and parasite loads suggest exchange between the Lakes and the Bight is limited, but these are unreliable indicators. Tagging, the only sure way of determining movement of fish, 
started in 2000 when about 1000 cod were tagged at various locations throughout the Lakes. By the autumn of 2001, 12 tags had been recovered; not enough to make any firm conclusions, but nevertheless, suggestive. The recaptured cod were tagged in St. Patrick's Channel between Baddeck and Nyanza during May in water less than $10 \mathrm{~m}$ deep and recovered during the winter by the 4VnSFA longliner in St. Andrew's Channel in water greater than $100 \mathrm{~m}$ deep. Contrary to Black's (1976) suggestion, this suggests that these cod, like their cousins in Sydney Bight, move to deeper, relatively warm water to overwinter within the Lakes (water of 2 to $4^{\circ} \mathrm{C}$, as opposed to $0^{\circ} \mathrm{C}$ and lower in the shallows). No Lakes tagged cod have yet been recaptured in Sydney Bight.

\section{Discussion}

Zoogeography. The animals that inhabit Nova Scotia's boreal region can be broadly divided into two groups. One group, by far the larger, is restricted to the temperatures normally experienced in this region; the smaller group can tolerate a much wider range of temperatures and can be found from temperate regions to the southern boundary of the Arctic zone. The first group comprises true boreal animals as well as some transitional zone (Arctic-boreal) animals. The boreal component includes cod, white hake, haddock, pollock, herring, longhorn sculpin, sea raven, cunner, rock gunnel and eelpout; Arctic-boreal representatives include alligatorfish and radiated shanny. Gaspareau and winter flounder are examples of the second group of temperature tolerant fish species. All of the above species have been reported from the Lakes.

Another two groups of animals distinguish the Bras d'Or Lakes from the rest of coastal Nova Scotia. They are isolated from their main centres of distribution and are restricted to narrow ranges of temperature. Surprisingly, one set of these isolated species are Arctic and the other are warm water temperate creatures more commonly found off the coast of Virginia (hence they are sometimes referred to as "Virginian enclave" species). Both groups are remnants of populations that were common at some point during the past geologic history of the Bras d'Or Lakes when climate ranged between distinctly Arctic to warmer than it is today. The Arctic animals colonised the Lakes as glaciers retreated after the last ice age about 10,000 years ago. Thereafter, the earth's climate began to warm until, until between 4,000 and 7,000 years ago, global temperatures were $2.0^{\circ} \mathrm{C}$ warmer than today. During this period, called the climatic optimum, warm temperate species invaded the Lakes.

The Arctic species continue to exist in the cold depths of St. Andrew's Channel, the North Basin and some of the deeper portions of the Bras d'Or Lake, where temperatures do not vary much above $0^{\circ} \mathrm{C}$ throughout the year (Petrie and Bugden, 2002). Several taxonomic groups are represented; the copepod, Microcalanus pusillus (Shih et al, 1988); the mysid shrimp, Mysis oculata (Black, 1958); polychaete worms, Clymenura polaris, Sabellides borealis and Lysippe labiata (Fournier and Pocklington, 1984); and foraminifera, Eggerella advena and Rheophax arctica (Vilks, 1967). Relict populations at the other end of the climatic scale are species that are adapted to warm water or require higher temperatures to reproduce successfully. The oyster, Crassostrea virginica requires warm temperatures for its gonads to develop properly and temperatures in excess of $20^{\circ} \mathrm{C}$ to trigger spawning. Similarly, it is thought that the windowpane flounder, Scophthalmus aquosus requires warm water to breed properly (Bigelow and Shroeder, 1953). Other examples of isolated warm-water enclave species in the Lakes, are the polychaete worms Euchone elegans, Polydora quadrilobata, and Myriochele heeri (Fournier and Pocklington, 1984). 
Biodiversity The wide range of habitats available within the Bras d'Or Lakes system allows for a corresponding diversity of species. The greatest number of species were collected in St. Andrew's Channel, the North Basin and the Great Bras d'Or Channel (Table X). The first two areas have the greatest range of depth, temperature and salinity and the Great Bras d'Or Channel is a transition zone between the outside Atlantic populations and those of the Lakes. North Basin has the highest overall ranking for species diversity (Table XI) and St. Andrew's and Great Bras d'Or Channels were second. Nyanza Bay, Baddeck Bay and St. Peter's Inlet rank low, but none of these areas is fully represented in taxonomic groups due to incomplete sampling of the Lakes by some surveys, so their rankings cannot be directly compared to the fully sampled areas. Certainly though, for those groups of organisms where they do have representation, they do not rank particularly high, with the exception of Baddeck Bay, where Black (1976) recorded his second highest number of fish species. Of the 4 areas that are fully represented, St. Patrick's Channel has the poorest variety of species, although Whycocomagh Bay, which was not sampled for copepods, is probably lower due to prevalent low oxygen at depth and low salinity near the surface (Petrie and Bugden, 2002; Strain and Yeats, 2002).

Table X Number of Species by Area.

\begin{tabular}{|c|c|c|c|c|c|c|c|c|c|c|c|c|}
\hline Organisms & GBC & $\mathrm{BB}$ & NyB & StPC & Why & StAC & NB & BDL & WB & StPI & DB & $\mathrm{EB}$ \\
\hline Foraminifera & 19 & 9 & 8 & 11 & 9 & 14 & 16 & 16 & 11 & - & 11 & 15 \\
\hline Algae & 26 & 18 & 20 & 19 & 23 & 26 & 30 & 20 & 20 & 19 & 21 & 20 \\
\hline Polychaetes & 48 & - & - & 16 & 16 & 40 & 27 & 38 & - & - & - & - \\
\hline Copepods & 10 & - & - & 7 & - & 14 & 10 & 10 & - & - & - & - \\
\hline Fish (1950-1) & 10 & 16 & - & 10 & 11 & 16 & 19 & - & - & - & - & - \\
\hline Fish (1967) & 15 & - & - & 13 & 6 & 16 & 17 & 16 & 12 & - & 15 & 9 \\
\hline Fish (1999-0) & 10 & 6 & 6 & 12 & 5 & 11 & 17 & 12 & 6 & 8 & 8 & 8 \\
\hline Total & 138 & 49 & 34 & 88 & 70 & 137 & 136 & 112 & 49 & 27 & 55 & 52 \\
\hline Average & 19.7 & 12.3 & 11.3 & 12.6 & 11.6 & 19.6 & 19.4 & 18.7 & 12.2 & 13.5 & 13.8 & 13 \\
\hline
\end{tabular}

GBC - Great Bras d'Or Channel; BB - Baddeck Bay; NyB - Nyanza Bay; StPC - St. Patrick's Channel; Why -Whycocomagh Bay; StAC - St. Andrew's Channel; NB - North Basin; BDL - Bras d'Or Lake; WB - West Bay; StPI - St. Peter's Inlet; DB - Denys Basin; EB - East Bay.

Fournier and Pocklington (1984) did not distinguish between St. Patrick's Channel and Whycocomagh Bay so the same values are assigned to each area in Tables XI and XII.

Table XI Ranked Species Totals by Area.

\begin{tabular}{lcccccccccccc}
\hline Organisms & GBC & BB & NyB & StPC & Why & StAC & NB & BDL & WB & StPI & DB & $\mathbb{E}$ \\
\hline Foraminifera & 1 & 9 & 11 & 6 & 9 & 5 & 2 & 2 & 6 & - & 6 & 4 \\
Algae & 2 & 12 & 5 & 10 & 4 & 2 & 1 & 5 & 5 & 10 & 9 & 5 \\
Polychaetes & 1 & - & - & 5 & 5 & 2 & 4 & 3 & - & - & - & - \\
Copepods & 2 & - & - & 5 & - & 1 & 2 & 2 & - & - & - & - \\
Fish(1950-1) & 4 & 2 & - & 4 & 5 & 2 & 1 & - & - & - & - & - \\
Fish(1967) & 4 & - & - & 6 & 9 & 2 & 1 & 2 & 7 & - & 4 & 8 \\
Fish(1999-0) & 5 & 9 & 9 & 2 & 12 & 4 & 1 & 2 & 9 & 6 & 6 & 6 \\
\hline Overall & 2 & 10 & 12 & 5 & 9 & 2 & 1 & 4 & 8 & 10 & 7 & 6 \\
\hline
\end{tabular}

Column headings as in Table X.

Abundance and distribution The quantity of animals found in the catch of a trawl net may reflect abundance, but may not because of sampling efficiency. Some bottom dwelling fish such as, eel-pout, which inhabit burrows in soft, muddy bottoms are 
normally passed over by the net; four-beard rockling, which, as plankton samples show are common, live in cavities under rocks, where they are also not vulnerable to the net. Rocky bottoms, which tear the net, are avoided when fishing, so any species preferring this type of habitat will be undersampled. Real changes in abundance of fish species, which are reflected in trawl catches, could be caused by a number of different factors ranging from ocean climate change to fishing pressures both within and outside the Lakes. Some species of fish do not appear to spawn within the Lakes, or at least not to the extent that self-sustaining populations can be established; therefore, their presence in the Bras d'Or is dependent on exchange with the ocean. In this case, changes in abundance may merely reflect changes on a larger scale in adjacent Sydney Bight. Haddock and pollock for example, were noted in earlier trawl surveys but not caught in the 1999/2000 survey. In Sydney Bight, from 1994 to 1998, the 4Vn Sentinel Survey caught $567 \mathrm{~kg}$ of haddock and $134 \mathrm{~kg}$ of pollock, compared to 400 tonnes of cod and 32 tonnes of American plaice. From the middle 1980s, haddock and pollock abundance decreased off north-east Nova Scotia probably because of fishing pressure, but for haddock, also because of a widespread decade long decrease in bottom temperatures in the area (Drinkwater et. al., 1999). Haddock, which had been rare in Sydney Bight are beginning to reappear perhaps due to a recent warming trend in bottom temperatures (Drinkwater et al., 1999). Possibly in time, they will reappear in the Lake system if stocks rebuild in Sydney Bight. Winter skate are very common both inside and outside the Lakes, with no break in their distribution between the two areas, probably indicating free exchange between Sydney Bight and the Lakes.

Whereas the presence of some species appears to be related to factors external to the Bras d'Or Lakes, the success of species such as herring, cod, winter flounder, plaice, yellowtail flounder, windowpane flounder and witch flounder seems more related to local events within the Lakes. Herring have been seriously depleted due to overfishing in the Lake and that fishery is now closed. Cod, and particularly winter flounder, appear to have increased in abundance since 1967. The closure of the bottom trawl fishery has probably allowed these stocks to rebuild. Plaice and yellowtail flounder are common outside the Lakes in Sydney Bight, therefore, the low numbers in the Bras d'Or would appear to indicate little or no movement between the two areas. Eggs and larvae of these two flatfish appear in plankton samples, but in very small numbers. These could originate with the few mature adults in the Lakes or possibly they may have been transported into the Lakes from Sydney Bight. Fig 9e indicates that juvenile yellowtail are present in the Lakes but there was no evidence of young plaice, as no individuals smaller than $30 \mathrm{~cm}$ were caught; thus it would appear there has been little or no recruitment to the plaice population in recent years. In the case of windowpane flounder, however, there can be no doubt that this species is a self-sustaining population within the Lakes for this species requires water around $20^{\circ} \mathrm{C}$ to reproduce (Bigelow and Shroeder, 1953) and these temperatures are rarely attained in outside coastal waters. Witch flounder, on the other hand, are found only in deep, cold water at the bottom of St. Andrew's Channel; in Sydney Bight they are common, but well offshore at depths over $100 \mathrm{~m}$. This species was a rare occurrence in the 1967 survey, and is probably even scarcer now since only one individual was caught in the 1999/2000 surveys. Whether this isolated pocket of witch flounder is a result of occasional larvae drifting into the Lakes and settling there, or whether there is a self-sustaining is difficult to say.

White hake appear to have been plentiful in the early 1950s, to have decreased substantially by 1967, and have increased since then. Draggers (bottom trawling) were active until 1992 when they were banned from operating in the Lakes. It is possible 
this fishing activity may have reduced the numbers of hake during the period represented by the 1967 survey, and that they rebounded after the prohibition on trawling. However, since white hake larvae are extremely rare in plankton samples, it is unlikely that hake spawn in the Lakes; their abundance is probably more dependent on the fortunes of the stock outside the Bras d'Or Lakes. However, there appears to be more to the white hake story. Recall that most of the catch of hake in the Lakes consisted of juvenile fish (Fig 9d), with a trend of increasing size from the entrance inward (Table VIII). This can be interpreted as a "seeding" from Sydney Bight of young hake, which move into the Lakes for the duration of their juvenile stage before moving back out into the Bight as near-mature adults. Possibly, the Bras d'Or Lakes is a nursery area for at least some portion of a white hake stock external to the Lakes. Similarly, in nearby St. Ann's Harbour, high numbers of small white hake, but no adults, have also been taken in an ongoing DFO inshore survey begun in 1991.

Of the fish species within the Bras d'Or Lakes, herring, cod, winter flounder, windowpane flounder, plaice, yellowtail flounder and probably witch flounder appear to be resident; whereas, white hake, winter skate and, in the past, haddock and pollock are more likely part of a continuous distribution with the larger, adjacent coastal area.

Are the Bras d'Or Lakes unique? At first glance the Bras d'Or Lakes, albeit far smaller, may appear similar to other large, more or less enclosed seas, such as the Baltic and Black. All three have been termed brackish, but the Bras d'Or Lakes by far the most salty, would not qualify as brackish according to Ekman's (1953) classification system. Apart from estuarine conditions where rivers enter, the salinity of the Bras d'Or Lakes ranges from about 20 at the surface to about 26 at depth (Krauel, 1976; Petrie and Bugden, 2002). In Ekman's scheme, the threshold salinity between brackish and saltwater is 17 to 20 . Thus the Baltic, which is mostly below 10, and with the highest values near the entrance only 15, is brackish. With the exception of deep waters, the Black Sea is mostly below 20 so it is a borderline case. Most of the glacial relicts described are from the Baltic and thus found in clearly brackish water. Arctic relicts from water more salty than 20 are very rare; only one or two have been reported (Ekman 1953). Therefore, the Bras d'Or Lakes with a number of relict species (and not confined to one taxonomic group) is a rarity. If we accept Ekman's definition of brackish, the Bras d'Or Lakes may be the only truly marine body of water that is home to so many glacial relicts. Furthermore, not only are there glacial relicts, but paradoxically also warm water enclave relicts. This must make the Lakes unique.

A better place to undertake marine ecosystem research would be hard to find. In addition to their unique assemblage of organisms and diverse habitats, the Bras d'Or Lakes have a number of other attributes which ideally suit them to marine research. Whereas the low flushing rates of the Lakes could be considered a liability, rendering them highly vulnerable to spills of pollutants, this same characteristic is a boon to biologists interested in the study of life histories of marine organisms. Usually it is very difficult to measure the survival rate of animals in the sea, particularly egg and larval stages, because one can never tell whether decreases in numbers are due to drift out of the study area or to on-site mortality. Plankton patches on the continental shelf can rarely be tracked for more than a few days. The low flushing, combined with the fact that the Lakes contain resident marine populations, provides a unique opportunity for quantitative studies of all stages of the life history of an organism. Throughout the Northwest Atlantic, many cod stocks were decimated in the late 1980s and have failed to recover after ten years or more. Why these stocks are not rebuilding is an open question. A study of the resident cod population in the Bras d'Or Lakes could provide valuable insights into the population dynamics of this species. 
As we have seen within the Bras d'Or Lakes, one can find species which normally would be found only by travelling south to Virginia and in the opposite direction north to Baffin Island in the Arctic. Amazingly, over $30^{\circ}$ of latitude are represented within distances of less than $10 \mathrm{~km}$ in Cape Breton's inland sea. Certainly, as McLachlin and Edelstein (1971) noted, "The great diversity of habitats in the Bras d'Or Lakes presents a unique opportunity for extensive ecological observations."

\section{Acknowledgements}

My sincere thanks to Bob Crawford for tracking down the MacDonald manuscript on the Bras d'Or Lakes survey. Thanks also to my able EFWC field technicians aboard the CCGC Navicula: Kyle Dicks, Lisa Paul, Bert Lewis, Allison Maclsaac, Vivian Bushell and especially to Captain Joe Bray and Cook/Deckhand Joe Randall for their cheerful cooperation. I am indebted to Jeff McRuer, and particularly Scott Wilson, of the Marine Fish Division at the Bedford Institute of Oceanography for providing logistic support. Most importantly, I wish to recognise Charlie Dennis, Director of the Unama'ki Institute of Natural Resources for initiating the Bras d'Or Lakes research programme and for his continuing support. Finally, thanks are due to Brian Petrie, John Tremblay and two anonymous reviewers for suggestions for improvement of the manuscript.

\section{References}

Beacham, T.D. 1982. Biology and exploitation of winter flounder (Pseudopleuronectes americanus) in the Canadian Maritimes area of the Northwest Atlantic Ocean. Can. Tech. Rept. Fish. Aquat. Sci. No. 1113, 33 p.

Beacham, T.D. 1983a. Variability in size and age at sexual maturity of white hake, pollock, longfin hake and silver hake in the Canadian Maritimes region of the Northwest Atlantic Ocean. Can. Tech. Rept. Fish. Aquat. Sci. No. 1157, 43 p.

Beacham, T.D. 1983b. Variability in size and age at sexual maturity of American plaice and yellowtail flounder in the Canadian Maritimes region of the Northwest Atlantic Ocean. Can. Tech. Rept. Fish. Aquat. Sci. No. 1196, 74 p.

Bigelow, H.B. and Shroeder, W.C. 1953. Fishes of the Gulf of Maine. Fish. Bull. US Fish Wildl. Serv. 53, viii +577 p.

Black, W.F. 1958. Biology of mysids of the Great Bras d'Or. MS. Rept. Fish. Res. Board Can. \#671.

Black, W.F. 1976. Aspects of the marine biology of the Great Bras d'Or. IN The proceedings of the Bras d'Or Lakes aquaculture conference, Sydney, Cape Breton. (Ed. M.G. McKay) College of Cape Breton Press, Sydney, N.S., 44-53.

Bousfield, E.L. and Thomas M.L.H. 1975. Postglacial changes in distribution of littoral marine invertebrates in the Canadian Atlantic region. Proc. N.S. Inst. Sci. 27, Suppl. 3: 47-60.

Bratty, J. 1990. Effect of temperature on egg hatching in three ascaridoid nematode species from seals. IN Population biology of sealworm (Pseudoterranova decipiens) in relation to its intermediate and seal hosts. (Ed. W. D. Bowen). Can. Bull. Fish. Aquat. Sci. 222: 27-39.

Bratty, J. and Stobo W.T. 1990. Group Report 2: Infection of Definitive Hosts. In Population biology of sealworm (Pseudoterranova decipiens) in relation to its 
intermediate and seal hosts. (Ed. W. D. Bowen). Can. Bull. Fish. Aquat. Sci. 222: 139-145.

Crawford, R.H., Webber, D.M. and Boutilier, G. 1982. The biology of herring from Bras d'Or Lake, Cape Breton. Nova Scotia. MS and Tech. Rept. N.S. Dept. Fish. 82-04, 66 p.

Dennis, C. 2001. (Eskasoni Fish and Wildlife Commission, Eskasoni, N.S.) Personal communication.

Denny, S., Clark, K.J., Power, M.J. and Stephenson, R.L. 1998. The status of the herring in the Bras d'Or Lakes in 1996-1997. Can. Stock Asses. Sec. Res. Doc. 98/80, 32 p.

Denny, S. 2001. (Eskasoni Fish and Wildlife Commission, Eskasoni, N.S.) Personal communication.

Drinkwater, K.F., Colbourne, E. and Gilbert D. 1999. Overview of environmental conditions in the NorthwestAtlantic in 1998. NAFO SCR. Doc. 99/36, Ser. No. N4094.

Ekman, S. 1953. Zoogeography of the sea. Sidgwick and Jackson Ltd., London.

Fournier, J. A. and Pocklington, P. 1984. The sublittoral polychaete fauna of the Bras d'Or Lakes, Nova Scotia, Canada. IN Proc. First Int. Polychaete Conf., Sydney. (Ed. P. A. Hutchings) Linnean Soc. N.S. Wales, 254-278.

Geen, G.H. 1965. Primary production in Bras d'Or Lake and other inland waters of Cape Breton Island, Nova Scotia. Ph. D. thesis, Dalhousie University, Halifax, N. S., $187 \mathrm{p}$.

Geen, G.H. and Hargrave, B.T. 1966. Primary and secondary production in Bras d'Or Lake, Nova Scotia, Canada. Verh. Inter. Limnol. 16: 333-340.

Krauel, D. 1976. A summary of the physical oceanography of the Bras d'Or Lake system. IN The proceedings of the Bras d'Or Lakes aquaculture conference, Sydney, Cape Breton. (Ed. M.G. McKay) College of Cape Breton Press, Sydney, N.S., 29-43.

Leim, A.H. and Scott, W.B. 1966. Fishes of the Atlantic coast of Canada. Bull. Fish. Res. Bd. Can. 155, 485 p.

MacDonald, K.F. 1968. Fish population assessment Bras d'Or Lake, Cape Breton Island. N.S. Dept. Fish., Resource Development Div., Pictou, 16 p.

Maclsaac, A. 2001. (Dept. Fisheries Oceans, Eastern N. S. Sydney Office) Personal communication.

McKay, M.G. (Ed.) 1976. Proceedings of the Bras d'Or Lakes Aquaculture Conference, held in Sydney, Cape Breton, 1975. College of Cape Breton Press, Sydney, N.S. xvii +312 p.

McLachlan, J. and Edelstein, T. 1971. Investigations of the marine algae of Nova Scotia. IX. A preliminary survey of the flora of Bras d'Or Lake, Cape Breton Island. Proc. N.S. Inst. Sci. 27: 11-22.

McLelland, G. 1990. Larval sealworm (Pseudoterranova decipiens) infections in benthic macrofauna. IN Population biology of sealworm (Pseudoterranova decipiens) in relation to its intermediate and seal hosts. (ed. W. D. Bowen). Can. Bull. Fish. Aquat. Sci. 222: 47-65.

McLelland, G., Misra, R. and Marcogliese, D 1983. Variations in abundance of larval anisakines, sealworm (Phocanema decipiens) and related species in cod and flatfish from the southern Gulf of St. Lawrence (4T) and the Breton shelf (4Vn). Can. Tech. Rep. Fish. Aquat. Sci. 1201: ix + 27 p.

McLelland, G., Misra, R. and Martell, D. 1990. Larval anisakine nematodes in various fish species from Sable Island Bank and vicinity. IN Population biology of sealworm (Pseudoterranova decipiens) in relation to its intermediate and seal hosts. (Ed. W. D. Bowen). Can. Bull. Fish. Aquat. Sci. 222: 83-118.

Nelson, J.A., Tang, Y. and Boutilier, R.G. 1994. Differences in exercise physiology 
between two Atlantic cod (Gadus morhua) populations from different environments. Physiol. Zool. 67(2): 330- 354.

Nelson, J. A., Tang, Y. and Boutilier, R.G. 1996. The effects of salinity change on the exercise performance of two Atlantic cod (Gadus morhua) populations inhabiting different environments. J. Exp. Biol. 199: 1295-1309.

O'Brien, L., Burnett, J. and Mayo, R. 1993. Maturation of nineteen species of finfish off the Northeast coast of the United States, 1985-1990. NOAA Tech. Rept. NMFS 113.

Petrie, B. and Bugden, G. 2002. The Physical Oceanography of the Bras d'Or Lakes. Proc. N. S. Inst. Sci . 42: 11-38.

Pogson, G.H., Taggart, C.T., Mesa, K.A. and Boutilier, R.G. 2001. Isolation by distance in the Atlantic cod, Gadus morhua, at large and small geographic scales. Evolution 55(1): 131-146.

Scott, D.M. 1952. The Greenland cod (Gadus ogac) in Cape Breton Island. Can. Field Nat. 66(5): 123-124.

Scott, D.M. and Black, W.F. 1960. Studies on the life-history of the ascarid Porrocaecum decipiens in the Bras d'Or Lakes, Nova Scotia, Canada. J. Fish. Res. Bd. Can. 17(6): 763-774.

Scott D.M. and Fisher, H.D. 1958. Incidence of the ascarid Porrocaecum decipiens in the stomachs of three species of seals along the southern Canadian Atlantic mainland. J. Fish. Res. Board Can. 15: 495-516.

Shih, C.-T., Marhue L., Barrett N. and Munro, R. 1988. Planktonic copepods of the Bras d'Or Lakes system, Nova Scotia, Canada. Hydrobiologica 167/168: 319-324.

Sinclair, M., Stobo, W.T. and Simon, J. 1980. 1979-1980 4Vn herring assessment. CAFSAC Res. Doc. 80/50.

Strain, P. and Yeats, P. 2002. The Chemical Oceanography of the Bras d'Or Lakes. Proc. N.S. Inst. Sci . 42: 39-66.

Tremblay, M.J. 2002. Large Epibenthic Invertebrates in the Bras d'Or Lakes. Proc. N. S. Inst. Sci. 42: xx-yy.

Vilks, G. 1967. Quantitative analysis of foraminifera in the Bras d'Or Lakes. Report of Bedford Institute of Oceanography. 67-1, 84 p.

Wright, R.A. 1976. Some production parameters at selected Bras d'Or sites. In The proceedings of the Bras d'Or Lakes aquaculture conference, Sydney, Cape Breton. (ed. M.G. McKay) College of Cape Breton Press, Sydney, N.S., 54-66.

Young, J. 1976. Aquaculture and chemistry of Bras d'Or. IN The proceedings of the Bras d'Or Lakes aquaculture conference, Sydney, Cape Breton. (Ed. M.G. McKay) College of Cape Breton Press, Sydney, N.S., 17-28.

(Received 1 March 2002) 


\section{Appendix}

Table Al Number of sets made by location in three trawl surveys in the Bras d'Or Lakes. Data from Black (1976), MacDonald (1968) and Lambert (this study).

\begin{tabular}{lccc}
\hline Location & $1951-1952$ & 1967 & $1999-2000$ \\
\hline Great Bras d'Or Channel & 6 & 8 & 1 \\
Baddeck Bay & 78 & - & 1 \\
St. Patrick's Channel & 9 & 6 & 4 \\
Nyanza Bay & - & - & 2 \\
Whycocomagh Bay & 42 & 4 & 4 \\
St. Andrew's Channel & - & 34 & 5 \\
North Basin & 36 & 17 & 7 \\
Bras d'Or Lake & - & 16 & 2 \\
Denys Basin & - & 11 & 2 \\
West Bay & - & - & 2 \\
St. Peter's Inlet & - & 8 & 4 \\
East Bay & - & 115 & 43 \\
\hline Total & 171 & &
\end{tabular}

Table AII Mean catch (numbers/tow) of selected species by location in Bras d'Or Lakes. 1951 \& 1952 combined (Black, 1976).

\begin{tabular}{|c|c|c|c|c|c|c|c|c|}
\hline Location & Cod & $\begin{array}{l}\text { Winter } \\
\text { flounder }\end{array}$ & $\begin{array}{l}\text { Window } \\
\text { pane } \\
\text { flounder }\end{array}$ & $\begin{array}{l}\text { Yellow } \\
\text { tail } \\
\text { flounder }\end{array}$ & Plaice & $\begin{array}{l}\text { White } \\
\text { hake }\end{array}$ & Skate & Total \\
\hline Gt. Bras d'Or Chn. & 11.3 & 222.7 & - & 17.8 & - & 0.7 & 0.5 & 253.0 \\
\hline Baddeck Bay & 12.1 & 43.2 & 1.3 & 2.4 & 1.7 & 32.6 & 0.6 & 93.9 \\
\hline St. Patrick's Chn. & 1.8 & 8.3 & 0.2 & 0.1 & 0.1 & 0.6 & 0.1 & 11.2 \\
\hline Whycocomagh Bay & 18.5 & 13.7 & $<0.1$ & $<0.1$ & 0.1 & 1.0 & $<0.1$ & 33.5 \\
\hline Kempt Head & 19.3 & 46.0 & 0.2 & 0.3 & 58.5 & 56.1 & 0.3 & 180.6 \\
\hline Average & 12.6 & 66.8 & 0.4 & 4.1 & 12.1 & 18.2 & 0.3 & 114.4 \\
\hline
\end{tabular}

Table AIII Mean catch ( $\mathrm{kg} /$ naut. mile) per set of selected species by location - 1967 survey (MacDonald, 1968). (Note, these data have not been adjusted for gear differences with the 1999/2000 survey.)

\begin{tabular}{lcccccccc}
\hline Location & Cod & $\begin{array}{c}\text { Winter } \\
\text { flounder }\end{array}$ & $\begin{array}{c}\text { Window } \\
\text { pane } \\
\text { flounder }\end{array}$ & $\begin{array}{c}\text { Yellow } \\
\text { tail } \\
\text { flounder }\end{array}$ & Plaice & $\begin{array}{c}\text { White } \\
\text { hake }\end{array}$ & Skate & Total \\
\hline Great Bras d'Or Chn. & 4.99 & 14.49 & 0.09 & 1.83 & 0 & 0.43 & 1.72 & 23.91 \\
St. Patrick's Channel & 5.02 & 17.98 & 0.04 & 0.33 & 0 & 0.54 & 0.15 & 24.20 \\
Whycocomagh Bay & 1.10 & 23.77 & 0.10 & 0 & 0 & 0.02 & 0 & 25.35 \\
St. Andrew's Channel & 6.77 & 1.44 & 0 & 0.01 & 20.67 & 0.01 & 0.10 & 29.00 \\
North Basin & 8.45 & 11.45 & 0.04 & 0.53 & 6.20 & 0.03 & 1.27 & 28.13 \\
Bras d'Or Lake & 4.40 & 7.74 & 0.15 & 0.42 & 0.03 & 0.02 & 0.30 & 13.64 \\
Denys Basin & 19.45 & 13.66 & 0.17 & 0 & 0 & 0.01 & 0.18 & 34.11 \\
West Bay & 5.20 & 9.02 & 0 & 0 & 0.88 & 0 & 0.86 & 15.96 \\
East Bay & 9.30 & 12.14 & 0.03 & 0 & 5.59 & 0 & 0 & 27.15 \\
\hline Average of Locations & 7.19 & 12.41 & 0.07 & 0.35 & 3.71 & 0.12 & 0.50 & 24.60 \\
\hline Average of all Sets & 7.52 & 8.98 & & 0.28 & 7.51 & 0.07 & 0.49 & \\
\hline
\end{tabular}


Table AIV Mean catch (kg/naut. mile) per set of selected species by location -1999/2000 surveys.

\begin{tabular}{lcccccccc}
\hline Location & Cod & $\begin{array}{c}\text { Winter } \\
\text { flounder }\end{array}$ & $\begin{array}{c}\text { Window } \\
\text { pane } \\
\text { flounder }\end{array}$ & $\begin{array}{c}\text { Yellow } \\
\text { tail } \\
\text { flounder }\end{array}$ & Plaice & $\begin{array}{c}\text { White } \\
\text { hake }\end{array}$ & Skate & Total \\
\hline Great Bras d'Or Chn. & 0 & 0.80 & 0 & 0.06 & 0 & 0.10 & 0.20 & 1.16 \\
Baddeck Bay & 0 & 1.40 & 0.40 & 0 & 0 & 0.50 & 0 & 2.30 \\
St. Patrick's Channel & 6.70 & 20.04 & 1.89 & 0 & 0 & 21.17 & 4.76 & 54.86 \\
Nyanza Bay & 0 & 6.30 & 0.64 & 0 & 0 & 0.00 & 0.17 & 7.11 \\
Whycocomagh Bay & 30.60 & 20.89 & 0.49 & 0 & 0 & 0 & 1.88 & 53.86 \\
St. Andrew's Channel & 29.26 & 18.92 & 0.41 & 0.52 & 7.21 & 0.08 & 0.06 & 57.00 \\
North Basin & 64.31 & 4.11 & 1.50 & 0.21 & 0 & 2.29 & 3.00 & 75.42 \\
Bras d'Or Lake & 46.70 & 29.35 & 3.11 & 0.22 & 0.68 & 5.82 & 0.73 & 86.61 \\
Denys Basin & 9.10 & 22.30 & 0.50 & 0 & 0 & 1.30 & 3.40 & 36.60 \\
West Bay & 50.80 & 218.90 & 0.35 & 0 & 0 & 0.79 & 0 & 270.84 \\
St. Peter's Inlet & 60.00 & 87.20 & 1.10 & 0 & 0 & 0.20 & 1.90 & 150.40 \\
East Bay & 21.90 & 114.80 & 1.00 & 0 & 0 & 0.92 & 0.79 & 139.41 \\
\hline Average of Locations & 26.53 & 45.75 & 0.95 & 0.08 & 0.66 & 2.76 & 1.45 & 78.13 \\
\hline Average of all Sets & 34.25 & 39.77 & 1.38 & 0.15 & 1.08 & 3.48 & 1.53 & \\
\hline
\end{tabular}

